WORKING PAPER \#651

PRINCETON UNIVERSITY

INDUSTRIAL RELATIONS SECTION

OCTOBER 2021

http://arks.princeton.edu/ark:/88435/dsp01g732dd130

\title{
Small Firms and the Pandemic: Evidence From Latin America*
}

\author{
Maria Elena Guerrero John Eric Humphries Christopher A. Neilson \\ UCLA Yale University Princeton University \\ Naomi Shimberg Gabriel Ulyssea \\ Yale University UCL
}

October 5, 2021

\begin{abstract}
This paper studies the effects of the COVID-19 pandemic on small businesses between March and November 2020 using new survey data on 35,000 small businesses in eight Latin American countries. We document that the pandemic had large negative impacts on employment and beliefs regarding the future, which in turn predict meaningful economic outcomes in the medium-term. Despite the unprecedented amount of aid, policies had limited impact for small and informal firms. These firms were less aware of programs, applied less, and received less assistance. This may have lasting consequences, as businesses that received aid reported better outcomes and expectations about the future.
\end{abstract}

Keywords: COVID-19, small business, Latin America

\footnotetext{
${ }^{*}$ Guerrero: Department of Economics, UCLA (mguerreroa@g.ucla.edu). Humphries: Department of Economics, Yale University (johneric.humphries@yale.edu). Neilson: Department of Economics, Industrial Relations Section, Princeton University (cneilson@princeton.edu). Shimberg: Tobin Center for Economic Policy, Yale University (naomi.shimberg@yale.edu). Ulyssea: Department of Economics, University College London (g.ulyssea@ucl.ac.uk). We would like to thank Princeton University's Industrial Relations Section for supporting this work. We thank JPAL-LAC, IPA, ConsiliumBots and the over thirty research assistants, data scientists, and surveyors for their enthusiasm, eagerness, and energy while implementing the project during extremely difficult times at the beginning of the pandemic. For more information, see the project website at https://covid19sbs.org/.
} 


\section{Introduction}

The Latin American region has been severely impacted by the COVID-19 pandemic, with only 8 percent of the world population but 32 percent of all deaths. ${ }^{1}$ Countries in the region implemented emergency public health measures with varying degrees of intensity within and across countries. In an attempt to mitigate the economic impacts of these policies, governments mobilized an unprecedented amount of aid to businesses, with particular focus on creating programs that provided subsidized loans and covered payroll. Despite the magnitude of these efforts, the region experienced the most severe economic retraction in the world in 2020 (IMF, 2021).

One of the key economic challenges faced by Latin American countries in the COVID-19 crisis - which is common to all developing countries - is the vast predominance of very small firms ${ }^{2}$ and unregistered (informal) firms (e.g. McKenzie and Bruhn, 2014; Hsieh and Olken, 2014; Ulyssea, 2020). ${ }^{3}$ These firms are likely to be disproportionately impacted by public health measures, as they tend to be concentrated in sectors directly affected by social distancing measures and lockdowns implemented to curb the pandemic (e.g., retail and in-person services) (OECD, 2020). Smaller firms may also be harder to reach by government policies due to substantially lower access to banks and financial services. This can hinder their ability to access subsidized loans, for example, which are the most common aid policy available in the region. Moreover, smaller firms may face greater challenges in receiving government aid due to difficulties in accessing, processing, and distilling the available information, or due to the time and effort often required to apply to these programs. In the case of informal firms, they may simply not qualify for any such program if formality is used as an eligibility criterion.

Despite the magnitude of the crisis and the policy response it entailed, there is limited evidence on its impacts on SMEs, particularly in developing countries. ${ }^{4}$ This paper uses new survey data from almost 35,000 small firms in Latin America ${ }^{5}$ to establish three empirical facts.

\footnotetext{
${ }^{1}$ As of June 14, 2021 according to data from the COVID-19 Data Repository by the Center for Systems Science and Engineering at Johns Hopkins University.

${ }^{2}$ In Latin America, Small and Medium Enterprises (henceforth SMEs) represent more than 95 percent of all firms and 67 percent of employment (IDB, 2020).

${ }^{3}$ Informal firms are those that operate at margin of the relevant laws and regulations related to registration, employment, and/or taxes. Measuring informality in the data is notoriously difficult. In our surveys, we define as informal firms as those that are not registered with their country's tax authority and/or do not pay social security contributions for their employees. Section 2.1 carefully describes the definitions of informality used in data collection.

${ }^{4}$ The main reason for this gap is lack of data on small businesses' outcomes, especially informal ones. When data are available, they come from administrative records, which by design only cover formal firms, and are rarely contemporaneously available for analysis. Indeed, the existing literature has predominantly focused on high-income countries. See Humphries et al. (2020), Granja et al. (2020), Chetty et al. (2020), Bartik et al. (2020), Cororaton and Rosen (2020), Bennedsen et al. (2009), Buchheim et al. (2020), Core and De Marco (2021), Kozeniauskas et al. (2020), and Cui et al. (2020).

${ }^{5}$ The survey was conducted in eight countries: Argentina, Bolivia, Brazil, Chile, Colombia, Dominican Republic,
} 
First, smaller firms (fewer than five full-time equivalent (FTE) employees) and informal firms were less aware of existing programs, less likely to apply for aid, and less likely to receive aid. Moreover, the gaps in awareness, applications, and receipt of aid grew over the course of the pandemic. These results indicate that the large presence of small firms, and in particular informal firms, was indeed a key obstacle for the effectiveness of aid programs implemented in the region. These outcomes are consistent with our review and systematization of almost 400 economic and health policies implemented in the region, which clearly shows that the majority of economic policies for firms had formality as a basic eligibility criterion. Second, firm owners were optimistic about future recovery at the beginning of the pandemic, but expectations deteriorated during the first weeks. Expectations improved in early May, after the announcement of most economic relief measures. Third, firms that received aid also reported improved expectations, higher revenues, lower exit, and higher rates of government approval, suggesting that aid has helped the firms that received it.

Our data come from daily surveys of small business owners collected from a large baseline intake, conducted between March 29 and May 31, 2020, as well as two smaller follow-up surveys conducted between June 25 and August 16 2020, and November 5 and December 20, $2020{ }^{6}$ These daily surveys provide high-frequency, repeated cross-sectional data that allow us to characterize the evolution of the firm owners' expectations and outcomes as the pandemic unfolded. Participants were recruited via social media advertisements targeted at owners of small businesses across Latin America that had been affected by COVID-19. The surveys collected information on firms' and firm owners' characteristics, including formality status of the firm, layoffs, closure, revenues lost, expectations about the future of their firm, awareness of government relief programs that could help their firm, access to aid, and approval of government actions. $^{7}$

Our first set of results shows that the smallest firms and informal firms were less aware of programs, less likely to apply for aid, and less likely to receive aid. Moreover, these gaps increased over the course of the pandemic. In April, firms with fewer than five FTE employees were 5 percentage points less likely to apply for aid; this gap widened to 7 and 10 percentage points in July and November, respectively. Similarly, the smallest firms were 7 percentage points less likely to report receiving aid in July, a gap which widened to 14 percentage points in November.

\footnotetext{
Mexico, and Peru.

${ }^{6}$ We refer to these surveys as the "April", "July", and "November" surveys as these were the months in which we received the majority of responses.

${ }^{7}$ Even though our survey was not designed to be representative of the universe of firms in these countries, it captures well the firm size distribution in each of the eight countries (see Section 2.1). While we fit the size distribution well, there are natural limitations to the survey methodology used, which are discussed in Section 2.1.
} 
These results hold when controlling for a rich set of covariates. The strongest predictor of awareness of programs is formality status. Informal firms were 8 percentage points less likely to be aware of programs at baseline, and this gap widened to 16 percentage points in November. Informal firms were also less likely to apply for and receive aid, which is consistent with the fact that informal firms were not eligible for the majority of programs. In most countries, the main policies available to informal workers were cash transfer programs, which target individuals and not firms.

In the second set of results, we show that most firm owners expected their business to recover within two years at the onset of the pandemic (81 percent). However, expectations deteriorated quickly, and this number reached a minimum of 69 percent by mid April. By mid May, after governments had announced billions of dollars of aid to SMEs, expectations of recovery in the next two years had almost reverted back to the initial level. We observe similar patterns in beliefs about ever recovering and probability of bankruptcy. While expectations improved dramatically, employment only slightly improved by mid May. Results from the follow-up surveys show that early expectations about recovery and future employment were significantly correlated with concrete business outcomes several months later, and therefore provide a useful measure to quickly understand the health of small businesses during a crisis.

In the third set of results, we show that businesses that received aid reported improved expectations, outcomes, and approval of the government in the short- and medium-term. In July, receiving aid was associated with a 0.25 standard deviation $(\sigma)$ improvement in expectations, a $0.29 \sigma$ improvement in business outcomes, and a $0.27 \sigma$ improvement in approval of the government. In November, these associations were weaker and less precise, suggesting that receiving aid may have had a short-term payoff without stabilizing firms several months later. As we do not have a source of random variation in access to aid, we cannot establish if these associations are causal. Indeed, the association may capture selection, with more capable firms being more informed and more likely to apply for aid. Nonetheless, the relationship holds after controlling for a rich set of characteristics of the firm and the owner, including baseline awareness of relief programs.

Our findings contribute to the literature on the economic impacts of COVID-19 on businesses in middle- and low-income countries and the efficacy of the associated policy response. ${ }^{8}$ Related work by Apedo-Amah et al. (2020) and Cirera et al. (2021) use data from the World Bank Business Pulse Survey (BPS) between April and September 2020 to analyze firms in low-,

\footnotetext{
${ }^{8} \mathrm{~A}$ larger literature studies the economic impacts of COVID-19 on households (see Bottan et al. (2020b) and Rahman and Matin (2020)).
} 
middle- and high-income countries. Consistent with our results, these papers find that small firms were significantly less likely to access support than larger firms. However, our unique survey design - which combines repeated daily cross-sections with a smaller panel of firmsallows us to document: (i) the role of information in firms' access to aid; (ii) the evolution of awareness of policies, expectations and outcomes; and (iii) the association between access to aid and firms' expectations, outcomes, and approval of government policies. Another set of recent papers uses experimental and quasi-experimental methods to study the impacts of social protection programs, such as cash transfers, implemented to mitigate the COVID-19 economic shock (e.g. Londoño-Vélez and Querubín, 2021; Banerjee et al., 2020; Bottan et al., 2020a). These papers do not focus on policies designed to aid firms, such as loan programs or employment retention schemes, but rather focus on policies that provide income transfers to poorer families. Finally, a third strand of literature focuses on a more conceptual discussion of the optimal structure of economic policy responses to COVID-19 in low- and middle-income countries, emphasizing the unique challenges presented by the high prevalence of informality (Gerard et al., 2020; Busso et al., 2020; Alfaro et al., 2020). Our paper builds on this literature by confirming several of the hypotheses and conjectures. In particular, we show that many small businesses may have missed out on pandemic relief, and that informal business may have been left behind altogether.

\section{Background and Data}

Our analysis focuses on eight Latin American countries: Argentina, Bolivia, Brazil, Chile, Colombia, Dominican Republic, Mexico, and Peru. As part of our analysis, we collected and coded information on nearly all major public health and economic policies in these eight countries using official national and sub-national government sources. This amounted to almost 400 policies across these countries. ${ }^{9}$ The top panel of Figure 1 shows the evolution of the number of economic and health policies in the region, as well as the number of COVID-19 related deaths. The first cases of COVID-19 were reported between March 2 and March 15, 2020. By March 20, all countries in our data had implemented ambitious containment measures, such as public schools closures, bans on intercity travel, and shutdown of non-essential businesses. ${ }^{10}$ Beginning in early April, governments created a variety of new economic policies and expanded existing

\footnotetext{
${ }^{9}$ See Appendix Section A for a complete list of policy sources, as well as the major policies for SMEs and informal workers in each country.

${ }^{10}$ Health and containment measures vary in their rigor and details between countries. To address these, and other differences that were largely fixed during our sample, all our analyses include country fixed-effects.
} 
ones to mitigate the effects of the pandemic. These measures were implemented at the national level by federal or central governments or in a decentralized manner at the sub-national level.

There was substantial heterogeneity in the scale and scope of economic resources announced across countries, as shown in the bottom panel of Figure $1 .^{11}$ However, the majority of aid to formal firms consisted of loan programs. These programs provided state-backed guarantees to the banks for the loans granted. For example, the Central Bank of Peru provided $\$ 18$ billion (equivalent to 8 percent of GDP) of guarantees to private banks to facilitate loans for SMEs through the Reactiva Perú program. Some countries, like Colombia and Brazil, directly distributed funds through state-owned banks. Most loan programs were available until funds ran out, usually a few months after the program's announcement.

\footnotetext{
${ }^{11}$ Figure 1 shows the amount of aid pledged by federal or central governments between March 11 and August 1 , 2020 as opposed to the amount of aid dispersed. Tracking the amount of aid implemented is much more difficult than tracking the amount of aid pledged. There was large variation across countries in terms of the effectiveness of policy implementation, and in the gap between resources announced and dispersed. For example, one of the aid programs in Peru (Suspensión Perfecta, received 29,000 applications, but only 450 had been approved by the end of June (Gamboa, 2020).
} 
Figure 1: Economic aid pledged during the first five months of the pandemic

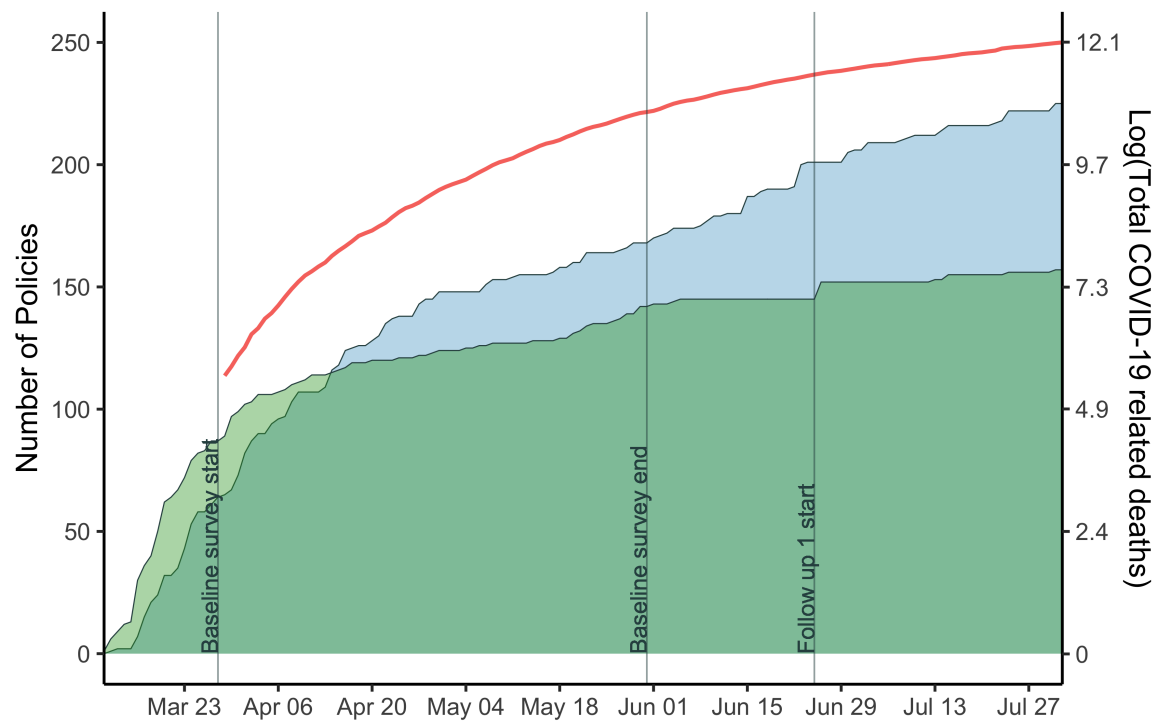

— Log(Total COVID-19 related deaths)

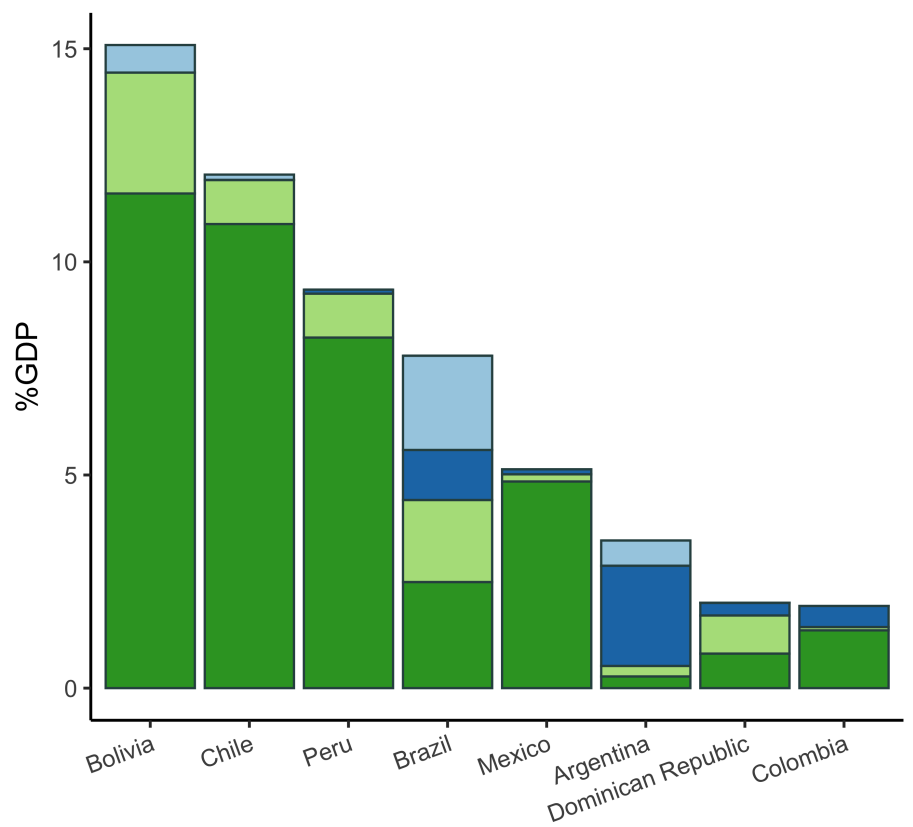

Note: Policy data is based on author's calculations using publicly-available data from official government sources. Our data reflect the amount of aid pledged by federal or central governments between March 11 and August 1, 2020; therefore discrepancies may arise with respect to eventual execution. Data on total COVID-19 deaths is from Our World in Data. Reliable COVID-19 mortality data is not available until late March. The top panel shows the number of public health policies (in green) and the number of economic policies (in blue) compared to the number of COVID-19 cases (in pink) in the eight surveyed countries. The vertical line shows the launch date of our survey on March 29, 2020. The bottom panel shows the amount of aid pledged as a percent of GDP. The "Tax/Other" category includes policies such as deferral of tax, utility, or debt payments, investment in infrastructure or education, or reductions in pension payments. See Appendix A for a complete list of policy details and sources, COVID-19 case and mortality data details and sources, and a discussion of estimates of excess mortality compared to COVID-19 mortality. 
Governments often coupled loan programs with measures to protect employment, such as funds to cover a certain number of months of salary or provisions allowing firm owners to defer taxes or social security contributions. In Argentina, the Emergency Assistance Program for Work and Production (3 percent of GDP) paid 50 percent of the April salaries of private sector workers whose companies had been affected by COVID-19. Like loan programs, the majority of employment programs were only available to firms for four to five months after the onset of the pandemic. See Appendix Table A2 for details on the largest loan and employment programs in each country, including expiration dates.

The majority of these economic policies had formality as a basic eligibility criterion, and thus informal firms largely only had access to social protection programs such as cash transfers. ${ }^{12}$ Governments designed new cash transfer programs for informal workers given that $65 \%$ of informal workers are not protected by any social safety net (Basto-Aguirre et al., 2020). However, these programs have traditionally been designed to target poor households, and do not necessarily mitigate job loss or income shocks (Gerard et al., 2020). In addition, new enrollment systems may not target the most vulnerable. Many new cash transfer programs required a computer or smartphone, but only 63 percent of adults in developing nations have access to a digital bank and only 21 percent have received government transfer payments to a digital account (World Bank, 2019).

\subsection{The COVID-19 International Small Business Survey}

To understand the impacts of COVID-19 on SMEs and the effectiveness of the government policy responses, we collected new survey data on SMEs' characteristics and outcomes, as well as owners' expectations about their businesses. ${ }^{13}$ The data consist of one large intake survey (March 29 to May 31, 2020) and two follow-up surveys (June 25 to August 16, 2020; November 5 to December 20, 2020).

All survey respondents were recruited through social media advertisements targeting small business owners. ${ }^{14}$ Respondents completed an online questionnaire in Qualtrics. The baseline survey contained a set of questions about firm characteristics, including firm size (as measured by the number of full- and part-time employees), the number of employees laid off since January, and formality status. ${ }^{15}$ Measuring firm informality in the data is a well-known difficult task (e.g. Ulyssea, 2020), especially across countries. To address differences in the institutional contexts,

\footnotetext{
${ }^{12}$ See Appendix Table A3 for a complete list of cash transfer programs targeted at informal workers.

${ }^{13}$ A similar survey is also available for the U.S., see Humphries et al. (2020).

${ }^{14}$ Appendix Section B provides more details about the survey and survey recruitment.

${ }^{15}$ We determine the number of full-time equivalent employment (FTE) as follows: $N_{\text {full-time }}+0.5\left(N_{\text {part-time }}\right)$
} 
we asked if firms were registered with the tax authority in Brazil, and if they were "Formal, making social security contributions" in the seven Spanish-speaking countries. ${ }^{16}$ The survey also asked small business owners to report how many employees they expected to lay off within the next two months, if they believed their businesses would recover in the next two years, if they thought their businesses would ever recover, and the probability that they would shut down or go bankrupt within the next six months. We also measure awareness of existing government programs available to help SMEs cope with the COVID-19 crisis. Specifically, the survey asks "Are you aware of any government programs that could help your business during this crisis?" Thus, it can capture both awareness of the program and comprehension of how the program works and who is eligible.

The overall baseline sample consists of 34,403 adult small business owners in the Latin American region who completed the baseline survey by May 31, 2020. ${ }^{17}$ Of those, 23,946 responses come from a short baseline survey with a more limited set of questions, while the remaining 10,457 responses come from a longer version of the survey, which included more detailed questions about access to programs. Due to resource constraints, we did not conduct the short baseline survey between April 19 and May 9, 2020 and therefore we do not have new intake during this time interval. ${ }^{18}$ We received 50 percent of baseline responses in the first two weeks of the survey. Responses were distributed relatively uniformly for the remainder of the sampling period, though there were fewer respondents in the last week of the survey.

Our first follow-up survey ran from June 25 to August 16, 2020 and was completed by 2,452 business owners. The second follow-up survey ran from November 6 to December 20 and was completed by 1,549 firm owners. Both follow-up surveys contacted past respondents with a new Qualtrics survey via email, and then followed-up with a phone-based survey when necessary. Responses were approximately equally split between these sources in both waves. ${ }^{19}$

Appendix Table C2 shows descriptive statistics of the three survey waves. At baseline, respondents had an average of 6.8 FTE employees in January, though the number of employees is right skewed, with a median of 3.5. Firms in our sample are nine years old on average and

\footnotetext{
${ }^{16}$ Since these definitions are not completely homogeneous, we repeated the analyses that involve informality excluding Brazil as a robustness check. See Appendix Table F5. All of the main conclusions hold.

${ }^{17}$ We arrive at this number after dropping businesses with more than 150 employees, which correspond to less than $0.6 \%$ of our sample. Appendix Section C maps the distribution of responses to each survey by country.

${ }^{18}$ See Appendix Section B for additional details on baseline data collection.

${ }^{19}$ Between May and June, the COVID-19 Small Business Study completed a randomized informational intervention. In this paper, we only report results from the non-treated groups of the follow-up surveys. Including the treatment group, the first follow-up survey was completed by 3,961 small business owners, and the second follow-up survey was completed by 2,540 small business owners. The results of the informational intervention will be discussed in a separate paper. The pre-trial registry can be found in the following link: https://www.socialscienceregistry . org/trials/5626.
} 
concentrated in the services and retail industries (73 percent of businesses). At baseline, 31 percent of firms were informal. The proportion of informal firm owners was similar in both of the follow-ups. The vast majority of the sample (92 percent) expected to recover eventually, and 68 percent expected to recover within the next two years. On average, awareness of government programs to help businesses was low (27 percent). At baseline, firms reported an average of 69 percent revenue loss, and 9 percent of firms had closed.

Though different firms responded to the survey at different dates, the relative firm size and formality distributions were consistent over the length of the survey ${ }^{20}$ While we did not construct the survey to be representative of the population of firms in Latin America, the firm size distribution in the data is similar to the firm size distribution in each country's administrative records. ${ }^{21}$ It is more difficult to perform similar checks of our measure of informality on secondary data, since there are few direct measures of the share of informal firms across countries. We thus compare the share of formal employees from each country in our survey to the share of the workforce that is formal according to International Labor Organization (ILO) data. As expected, our survey has a higher share of formal workers since it does not capture informal employees in formal firms and our survey is likely to miss part of the very low-skill, self employed population (see Appendix C for additional details on this comparison).

Given the survey methodology, there are some natural limitations to the survey data. First, social media recruitment may result in a sample that is biased in ways not easily observed. Second, we may have missed respondents whose firms' shut down very early in the pandemic and no longer self-identified as small business owners. Third, there is attrition in the follow-up surveys. Despite these limitations, we believe the survey methodology provided a useful way to affordably reach a large number of small business owners early in the pandemic when other data were scarce.

\section{Empirical Findings}

This section outlines three sets of results. First, we provide evidence that the smallest businesses and informal businesses were substantially less informed about available government programs, less likely to apply for these programs, and less likely to receive aid. Second, we document how expectations and layoffs evolved from March 29 to May 31, 2020. Third, we document that receiving aid was associated with notable improvements in business outcomes, expectations

\footnotetext{
${ }^{20}$ See Appendix Figure C2.

${ }^{21}$ See Appendix Figure C3.
} 
about the future, and overall approval of the government.

\subsection{Awareness and Access to Aid}

We start by characterizing access to aid by small business owners. One distinguishing feature of our survey is that we have information on small business owners' awareness about existing programs designed to help them during the COVID-19 crisis. Even though awareness is a key determinant of access to aid (as we discuss below), general awareness levels were low in Latin America. While awareness increased over the first three weeks of the survey, less than 50 percent of firm owners on average were aware of any program that could help their business. Even fewer firm owners were aware of programs that covered wages or offered subsidized loans. Low awareness of programs in Latin America contrasts with the high awareness levels in U.S., where over 80 percent of small business owners reported being aware of programs by April 16, 2020 (Humphries et al., 2020).

The first panel of Table 1 reports results from regressing an indicator for awareness of programs on firm characteristics. In April, firms with fewer than five FTE employees were 7 percentage points less likely to be aware of programs. In addition, Appendix Figure D1 shows that businesses with more than five employees became aware of programs much more quickly than businesses with fewer than five FTE employees. Although lower levels of awareness could be consistent with smaller firms having less need for assistance and thus remaining less informed, our data does not support this conjecture. At baseline, firms with fewer than five FTE employees were 1 percentage point less likely to report that they expected to ever recover, and 2 percentage points more likely to expect future bankruptcy or permanent closure relative to larger firms. Moreover, as we discuss in the following sections, access to aid is significantly associated with better outcomes and expectations, even among smaller firms.

Even when conditioning on firm size, the strongest predictor of awareness of programs is firms' formality status. Informal firms were 8 percentage points less likely to be aware of programs at baseline, and this gap widened to 16 percentage points in November. This is intuitive, as informal firms were not eligible for the majority of programs and they have low rates of bancarization, which can limit owners' ability to apply for and receive some types of government assistance. Typically, the main policy available to informal firm owners were cash transfer programs, which target individuals, not firms.

As shown in the second and third panels of Table 1, we find a similar pattern for applications and access to aid: more vulnerable firms were less likely to apply for and receive aid, and the gap between the groups widened over time. The smallest firms were less likely to apply for aid in each point in time, though the gap was largesf in November, when the smallest firms were 10 
percentage points less likely to apply. In addition, the smallest firms were less likely to receive aid, with a gap of 14 percentage points in November. ${ }^{22}$ Informal firms were also significantly less likely to apply for and receive aid, as well as firm owners with less education. Appendix Table F1 breaks out firms with 0 employees (which are more likely to be sole-proprietors or self-employed). We show that firms with 0.5 to 4.5 employees remain substantially less likely to apply for and to receive aid than larger firms.

Finally, even after controlling for other characteristics, early awareness was associated with an increase in applications and access to aid. Awareness of programs at baseline was associated with an 18 and 20 percentage point increase in applications in July and November, as well as a 13 and 15 percentage point increase in the probability of receiving aid in July and November, respectively.

Table 1: Access to aid and firm characteristics

\begin{tabular}{|c|c|c|c|c|c|c|c|c|c|}
\hline & \multicolumn{3}{|c|}{ Aware of programs } & \multicolumn{3}{|c|}{ Applied } & \multicolumn{3}{|c|}{ Received help } \\
\hline & April & July & Nov & April & July & Nov & April & July & Nov \\
\hline $0-4.5 \mathrm{FTE}$ & $\begin{array}{c}-0.066^{* * *} \\
(0.011)\end{array}$ & $\begin{array}{c}-0.059^{* *} \\
(0.025)\end{array}$ & $\begin{array}{c}-0.083^{* * *} \\
(0.028)\end{array}$ & $\begin{array}{c}-0.054^{* * *} \\
(0.009)\end{array}$ & $\begin{array}{c}-0.064^{* * *} \\
(0.023)\end{array}$ & $\begin{array}{c}-0.104^{* * *} \\
(0.027)\end{array}$ & $\begin{array}{l}-0.009 \\
(0.008)\end{array}$ & $\begin{array}{c}-0.070^{* * *} \\
(0.018)\end{array}$ & $\begin{array}{c}-0.135^{* * *} \\
(0.023)\end{array}$ \\
\hline Informal & $\begin{array}{c}-0.081^{* * *} \\
(0.014)\end{array}$ & $\begin{array}{c}-0.071^{* *} \\
(0.031)\end{array}$ & $\begin{array}{c}-0.160^{* * * *} \\
(0.033)\end{array}$ & $\begin{array}{c}-0.036^{* * *} \\
(0.009)\end{array}$ & $\begin{array}{c}-0.154^{* * *} \\
(0.029)\end{array}$ & $\begin{array}{c}-0.137^{* * *} \\
(0.030)\end{array}$ & $\begin{array}{l}-0.006 \\
(0.008)\end{array}$ & $\begin{array}{c}-0.098^{* * *} \\
(0.019)\end{array}$ & $\begin{array}{c}-0.085^{* * *} \\
(0.021)\end{array}$ \\
\hline Years of schooling & $\begin{array}{c}0.020^{* * *} \\
(0.003)\end{array}$ & $\begin{array}{c}0.016^{* * *} \\
(0.006)\end{array}$ & $\begin{array}{l}-0.003 \\
(0.007)\end{array}$ & $\begin{array}{c}0.006^{* * *} \\
(0.002)\end{array}$ & $\begin{array}{c}0.003 \\
(0.006)\end{array}$ & $\begin{array}{c}0.005 \\
(0.007)\end{array}$ & $\begin{array}{c}0.008^{* * *} \\
(0.002)\end{array}$ & $\begin{array}{l}0.009^{* *} \\
(0.005)\end{array}$ & $\begin{array}{l}0.010^{*} \\
(0.006)\end{array}$ \\
\hline Aware of programs (April) & & $\begin{array}{c}0.333^{\text {**** }} \\
(0.026)\end{array}$ & $\begin{array}{c}0.243^{\text {*** }} \\
(0.030)\end{array}$ & $\begin{array}{c}0.185^{\text {*** }} \\
(0.009)\end{array}$ & $\begin{array}{c}0.179^{* * *} \\
(0.024)\end{array}$ & $\begin{array}{c}0.201^{* * *} \\
(0.030)\end{array}$ & $\begin{array}{c}0.077^{* * *} \\
(0.008)\end{array}$ & $\begin{array}{c}0.133^{* * *} \\
(0.020)\end{array}$ & $\begin{array}{c}0.151^{\text {*** }} \\
(0.026)\end{array}$ \\
\hline Recover in two years (April) & $\begin{array}{c}0.060^{* * *} \\
(0.011)\end{array}$ & $\begin{array}{l}0.044^{*} \\
(0.026)\end{array}$ & $\begin{array}{c}0.022 \\
(0.030)\end{array}$ & $\begin{array}{c}-0.009 \\
(0.009)\end{array}$ & $\begin{array}{l}-0.018 \\
(0.023)\end{array}$ & $\begin{array}{c}0.031 \\
(0.028)\end{array}$ & $\begin{array}{c}0.007 \\
(0.008)\end{array}$ & $\begin{array}{c}0.017 \\
(0.018)\end{array}$ & $\begin{array}{c}0.006 \\
(0.023)\end{array}$ \\
\hline Mean & 0.349 & 0.459 & 0.474 & 0.156 & 0.433 & 0.395 & 0.045 & 0.17 & 0.199 \\
\hline$N$ & 8,426 & 1,488 & 1,310 & 7,643 & 1,984 & 1,311 & 3,184 & 1,821 & 1,307 \\
\hline $\begin{array}{l}\text { Notes: }{ }^{* * *} p<0.01,{ }^{* *} \\
\text { he survey was complete } \\
\text { put coefficients were lars } \\
\text { he outcomes. The omit } \\
\text { neasurement in April. S } \\
\text { April columns of Applied } \\
\text { Alternative specifications } \\
\text { irms with zero employee }\end{array}$ & $\begin{array}{l}\text { categ } \\
\text { ple siz } \\
\text { d Rec } \\
\text { these }\end{array}$ & $\begin{array}{l}<0.1 \\
\text { ions al } \\
\text { stically } \\
\text { for fir } \\
\text { aange } \\
\text { h help } \\
\text { lts are }\end{array}$ & $\begin{array}{l}\text { All regr } \\
\text { nclude } \\
\text { rnifican } \\
\text { ize bins } \\
\text { result } \\
\text { ecause } \\
\text { uded in }\end{array}$ & $\begin{array}{l}\text { within- } \\
\text { asked f } \\
\text { pendix }\end{array}$ & firm o & $\begin{array}{l}\text { The } \\
\text { s abou } \\
\text { de a ba }\end{array}$ & $\begin{array}{l}\text { s. Ar } \\
\text { ige in } \\
\text { e out } \\
\text { ed pa }\end{array}$ & $\begin{array}{l}\text { and di } \\
\text { and } R e \\
\text { of the size } \\
\text { of resu }\end{array}$ & $\begin{array}{l}\text { the d } \\
\text { 's gend } \\
\text { ot pred } \\
\text { refer } \\
\text { tween } \\
\text { plicati } \\
\text { separat }\end{array}$ \\
\hline
\end{tabular}

\subsection{Firms' Expectations}

A second distinguishing feature of our survey is that it provides information about owners' expectations about the future of their businesses. The baseline survey provides high-frequency, repeated cross-sectional data that allow us to characterize the evolution of layoffs and expectations from March 29 through May 31, 2020, with a two-week gap between April 19 and May 9, 2020 when we did not collect new survey responses. These data provide insight into how businesses adjusted to the initial shock, and how their expectations about the future evolved.

\footnotetext{
${ }^{22}$ The change in sample size between the April columns of Applied and Received help is because we asked fewer firm owners about the outcome of their application.
} 
Figure 2 summarizes changes in expectations and employment over time. We regress each outcome on dummies for the week in which the baseline survey was taken, country fixed effects, day of week the survey was taken, and baseline characteristics of the firm and its owner. While the confidence intervals are not small, the point estimates in Figures 2a, 2b, and 2c show that expectations about the future declined sharply during the first month of the pandemic, reaching a low during the week of April 15, when strict social distancing measures had been announced in all of the study countries. ${ }^{23}$

Figure 2 also shows that expectations improved in early May, after the announcement of the majority of economic relief measures. The timing suggests the announcements may have affected expectations, though our data do not allow us to directly establish this link. Nevertheless, we are able to directly examine whether access to aid had a positive impact on firm owners' expectations. As Table 3 shows, receiving aid is associated with an increase of 0.29 standard deviation in our expectations index (more details in the following subsection).

Though these expectation variables constitute subjective measures of firm owners' beliefs, results from the follow-up surveys show that they were significantly correlated with concrete firm outcomes several months later. Table 2 shows how early expectations were strongly associated with business closure, percent revenue loss, and past layoffs in July and November. A 1 percent increase in expected probability of bankruptcy was associated with 0.11 and 0.13 percent increase in actual closures in July and November, respectively. Firms that expected future layoffs at baseline were 0.11 and 0.13 percent more likely to report past layoffs in both July and November. Similarly, better expectations at baseline were associated with significantly less revenue loss in the six months between March and September 2020. ${ }^{24}$ Consistent with these results, Figure $2 \mathrm{~d}$ shows the evolution of the share of firms that had laid off any workers since January. The behavior of this concrete outcome is very consistent with the measures of expectations, especially in the first four weeks. During this period, the proportion of small businesses that had laid off at least one employee increased by approximately 20 percentage points. In the last two weeks of the survey, past layoffs leveled out.

These results suggest that contemporary measures of subjective expectations can be useful ex-ante predictors of concrete business outcomes several months later. ${ }^{25}$ Measures of subjective

\footnotetext{
${ }^{23}$ See Appendix Section F for a table version of this figure. These trends are consistent with the testimonials we collected from firm owners during this time, some of which are presented in Appendix H.

${ }^{24}$ In order to make the revenue loss question comparable across respondents, we asked about a fixed period of time. In the July follow up the question was still prospective ("What is your best guess for your firms' percent revenue loss in the six months between March and September 2020 because of COVID-19?"), whereas in the November follow up it was about realized income losses ("What is your best estimate of your firms' percent revenue loss between March and September 2020 because of COVID-19?").

${ }^{25}$ This is not to imply that we are taking a stance on if firms' expectations are rational or if there may be systematic
} 
expectations could be an important tool for policy makers, especially when evaluating policies shortly after their introduction.

Figure 2: Evolution of expectations and employment

(a) Expect to recover in two years

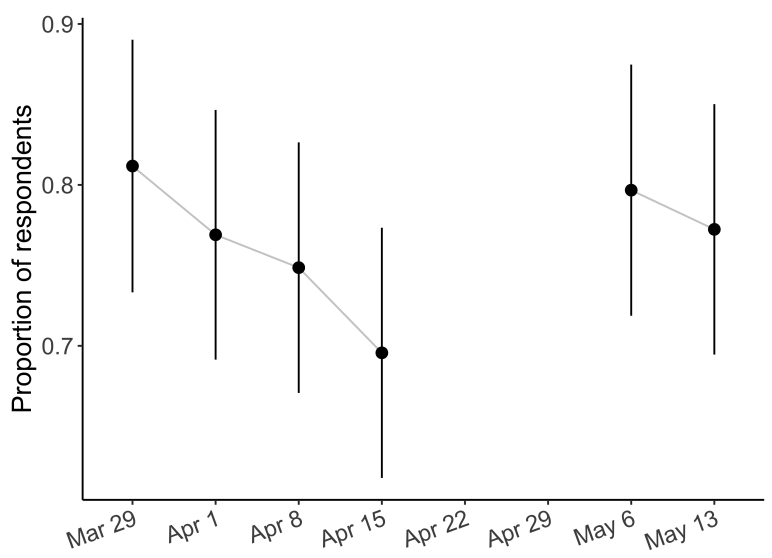

(c) Expect future layoffs

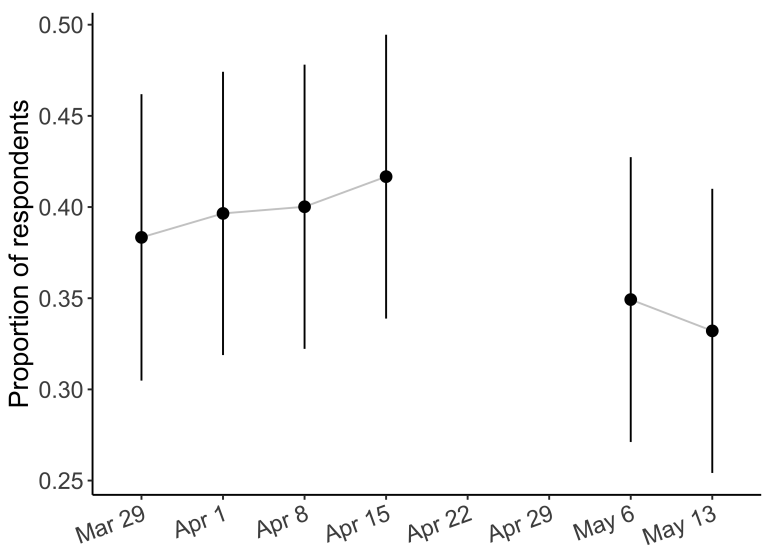

(b) Probability of bankruptcy

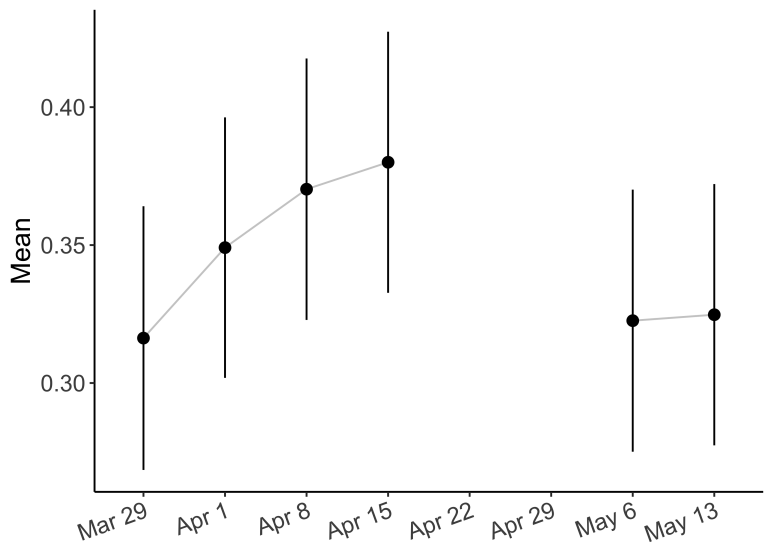

(d) Laid off at least one employee

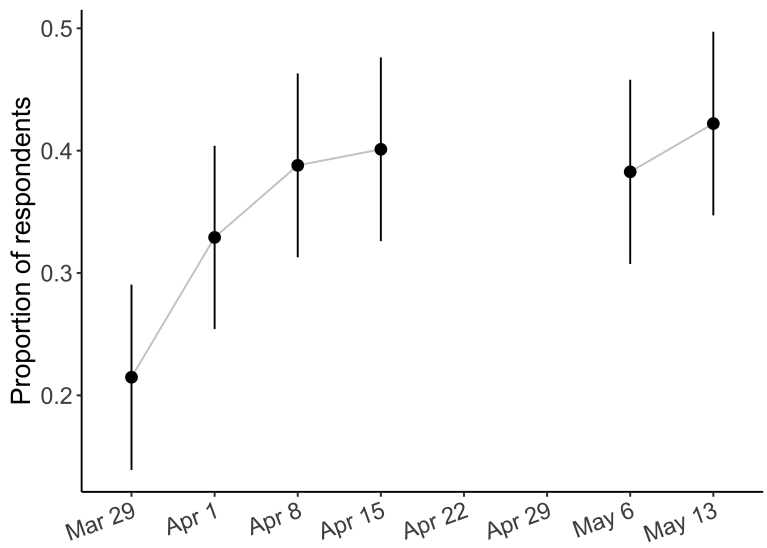

Note: Figures report regression-adjusted proportion of respondents. Figure shows results from baseline survey between March 29 and May 19, 2020. There was no data collection during the weeks of April 22 and April 29, 2020. Probability of bankruptcy is defined as probability of bankruptcy in the next six months. Expect future layoffs is defined as expect future layoffs in the next 60 days. Laid off at least one employee is defined as laid off at least one employee in the past 60 days. All regressions control for a third order polynomial in the number of full-time equivalent employees in January, country dummies, years of education of the owner, gender, age group dummies, firm sector, and firm age. The omitted group for countries is Argentina. The omitted group for firm owner age is 35-39 years old. 95\% confidence intervals are reported. A table version of this figure can be found in Appendix D.

biases, but rather that they may be useful predictors of later outcomes. 
Table 2: Early expectations and later outcomes

\begin{tabular}{|c|c|c|c|c|c|c|c|c|}
\hline \multirow[b]{2}{*}{ Beliefs in April } & \multicolumn{8}{|c|}{ Business closed } \\
\hline & July & Nov. & July & Nov. & July & Nov. & July & Nov. \\
\hline Recover in two years & $\begin{array}{c}-0.049^{* * *} \\
(0.012)\end{array}$ & $\begin{array}{c}-0.064^{* * *} \\
(0.018)\end{array}$ & & & & & & \\
\hline Recover ever & & & $\begin{array}{c}-0.096^{* * *} \\
(0.029)\end{array}$ & $\begin{array}{c}-0.117^{* * *} \\
(0.041)\end{array}$ & & & & \\
\hline Prob. bankrupt & & & & & $\begin{array}{c}0.107^{* * *} \\
(0.020)\end{array}$ & $\begin{array}{c}0.130^{* * *} \\
(0.027)\end{array}$ & & \\
\hline Expect future layoffs & & & & & & & $\begin{array}{c}0.029^{* * *} \\
(0.010)\end{array}$ & $\begin{array}{l}0.033^{* *} \\
(0.014)\end{array}$ \\
\hline Mean dep. var & 0.061 & 0.069 & 0.061 & 0.069 & 0.061 & 0.069 & 0.061 & 0.069 \\
\hline \multirow[t]{2}{*}{$N$} & 2,204 & 1,364 & 2,204 & 1,363 & 2,204 & 1,364 & 2,137 & 1,327 \\
\hline & \multicolumn{8}{|c|}{ Past layoffs } \\
\hline Beliefs in April & July & Nov. & July & Nov. & July & Nov. & July & Nov. \\
\hline Recover in two years & $\begin{array}{c}0.018 \\
(0.023)\end{array}$ & $\begin{array}{c}-0.080^{* * *} \\
(0.030)\end{array}$ & & & & & & \\
\hline Recover ever & & & $\begin{array}{c}0.041 \\
(0.042)\end{array}$ & $\begin{array}{c}-0.142^{* * *} \\
(0.052)\end{array}$ & & & & \\
\hline Prob. bankrupt & & & & & $\begin{array}{c}0.116^{* * *} \\
(0.040)\end{array}$ & $\begin{array}{c}0.217^{* * *} \\
(0.050)\end{array}$ & & \\
\hline Expect future layoffs & & & & & & & $\begin{array}{c}0.111^{* * *} \\
(0.023)\end{array}$ & $\begin{array}{c}0.131^{* * *} \\
(0.030)\end{array}$ \\
\hline Mean dep. var & 0.542 & 0.651 & 0.542 & 0.651 & 0.542 & 0.651 & 0.542 & 0.651 \\
\hline \multirow[t]{2}{*}{$N$} & 2,202 & 1,241 & 2,202 & 1,241 & 2,202 & 1,241 & 2,135 & 1,209 \\
\hline & \multicolumn{8}{|c|}{ Percent revenue loss (March - September) } \\
\hline Beliefs in April & July & Nov. & July & Nov. & July & Nov. & July & Nov. \\
\hline Recover in two years & $\begin{array}{c}-6.536^{* * *} \\
(1.663)\end{array}$ & $\begin{array}{c}-6.302^{* * *} \\
(1.560)\end{array}$ & & & & & & \\
\hline Recover ever & & & $\begin{array}{c}-12.128^{* * *} \\
(2.686)\end{array}$ & $\begin{array}{c}-8.409^{* * *} \\
(2.536)\end{array}$ & & & & \\
\hline Prob. bankrupt & & & & & $\begin{array}{c}28.689^{* * *} \\
(2.876)\end{array}$ & $\begin{array}{c}25.702^{* * *} \\
(2.657)\end{array}$ & & \\
\hline Expect future layoffs & & & & & & & $\begin{array}{c}7.764^{* * *} \\
(1.649)\end{array}$ & $\begin{array}{c}5.753^{* * *} \\
(1.566)\end{array}$ \\
\hline Mean dep. var & 68.602 & 70.961 & 68.602 & 70.961 & 68.602 & 70.961 & 68.602 & 70.961 \\
\hline$N$ & 1,177 & 1,262 & 1,177 & 1,261 & 1,177 & 1,262 & 1,131 & 1,227 \\
\hline
\end{tabular}

\subsection{Access to Aid and Firms' Outcomes}

In this section we assess the relationship between receiving aid and firms' expectations, outcomes, and approval of government actions. While we control for a rich set of firms' and owners' characteristics, this section only highlights the associations between aid and firms' outcomes as we do not have random variation in access to aid.

Given the survey has many measures associated with firms' expectations, outcomes, and approval of government programs, we use principal component analysis (PCA) to reduce the dimensionality and facilitate the discussion of results. The "expectation index" is composed of questions about recovery, future layoffs, and future closure or bankruptcy; the "outcome 
index" is composed of questions about revenue loss, past layoffs, and permanent closure; and the "approval index" is composed of questions about approval of policies for SMEs, workers, and the government's overall response. ${ }^{26}$ We regress z-scores of each index on indicators for receiving aid and the same controls used in previous sections: a third order polynomial in the number of FTE employees in January, firm sector dummies, firm age, country dummies, day of the week the survey was completed, owners' awareness of programs at baseline, years of education dummies, gender, and age group dummies.

The first three columns in Table 3 show results for all firms, while columns four to nine show results by firm size. Overall, receiving aid was associated with notable improvements in expectations, outcomes, and approval of government programs at each point in time. In the short-term, receiving aid was associated with a 0.27 standard deviation $(\sigma)$ improvement in expectations and a $0.49 \sigma$ improvement in approval of government actions. As Appendix Table F6 shows, improvements in expectations were driven by decreases in expectations of future layoffs and bankruptcy. The magnitude of the association between receiving aid and approval of the government in the short-term was particularly large for the smallest firms.

Four months later, receiving aid was associated with a $0.25 \sigma$ increase in expectations, a $0.29 \sigma$ improvement in business outcomes, and a $0.27 \sigma$ increase in approval. The increase in business outcomes and expectations was driven by firms with more than five FTE employees, who may face fewer barriers to receiving aid. In November, the association between receiving aid and improved expectations and business outcomes was significantly weaker. While we cannot establish a causal relationship, this may have been related to many programs expiring in late 2020 or early $2021 .^{27}$

In the Appendix Section F, we report the association between receiving aid and the individual outcomes used to create each index. In addition, we show that our results hold when controlling for COVID-19 cases per million people, deaths per million people, and government stringency. We also restrict the analysis to the sub-sample of respondents who completed the baseline and either one of the follow-up surveys. This is a smaller sample and estimates are less precise, but we find similar though smaller coefficients on the association between receiving aid and expectations, outcomes, and approval.

\footnotetext{
${ }^{26}$ See Appendix E for details on principal component analysis and fit.

${ }^{27}$ Appendix Tables A2 and A3 show expiration dates for each program.
} 
Table 3: Access to aid and expectations, outcomes, and approval of government policies

\begin{tabular}{|c|c|c|c|c|c|c|c|c|c|}
\hline & \multicolumn{3}{|c|}{ All } & \multicolumn{3}{|c|}{$0-4.5$ FTE } & \multicolumn{3}{|c|}{$5+$ FTE } \\
\hline & April & July & Nov & April & July & Nov & April & July & Nov \\
\hline Expectation index & $\begin{array}{c}0.272^{* * *} \\
(0.093)\end{array}$ & $\begin{array}{c}0.253^{* * *} \\
(0.062)\end{array}$ & $\begin{array}{c}0.166^{* *} \\
(0.069)\end{array}$ & $\begin{array}{c}0.267^{*} \\
(0.142)\end{array}$ & $\begin{array}{l}0.171^{*} \\
(0.090)\end{array}$ & $\begin{array}{c}0.086 \\
(0.104)\end{array}$ & $\begin{array}{l}0.279^{* *} \\
(0.125)\end{array}$ & $\begin{array}{c}0.357^{* * *} \\
(0.089)\end{array}$ & $\begin{array}{l}0.194^{* *} \\
(0.094)\end{array}$ \\
\hline Outcome index & $\begin{array}{c}0.104 \\
(0.075)\end{array}$ & $\begin{array}{c}0.288^{* * *} \\
(0.057)\end{array}$ & $\begin{array}{l}0.173^{* *} \\
(0.073)\end{array}$ & $\begin{array}{l}0.188^{*} \\
(0.107)\end{array}$ & $\begin{array}{l}0.138^{*} \\
(0.081)\end{array}$ & $\begin{array}{l}0.005 \\
(0.111)\end{array}$ & $\begin{array}{c}0.037 \\
(0.098)\end{array}$ & $\begin{array}{c}0.417^{* * *} \\
(0.078)\end{array}$ & $\begin{array}{l}0.223^{* *} \\
(0.097)\end{array}$ \\
\hline Approval index & $\begin{array}{c}0.485^{* * *} \\
(0.113)\end{array}$ & $\begin{array}{c}0.268^{* * *} \\
(0.065)\end{array}$ & $\begin{array}{c}0.441^{* * *} \\
(0.077)\end{array}$ & $\begin{array}{c}0.716^{* * *} \\
(0.166)\end{array}$ & $\begin{array}{c}0.076 \\
(0.087)\end{array}$ & $\begin{array}{l}0.229^{* *} \\
(0.113)\end{array}$ & $\begin{array}{l}0.305^{* *} \\
(0.146)\end{array}$ & $\begin{array}{c}0.407^{* * *} \\
(0.096)\end{array}$ & $\begin{array}{c}0.558^{* * *} \\
(0.106)\end{array}$ \\
\hline Number of respo & 3,184 & 1,987 & 1,470 & 1,825 & 1,188 & 869 & 1,359 & 799 & 601 \\
\hline
\end{tabular}

Notes: ${ }^{* * *} p<0.01,{ }^{* *} p<0.05,{ }^{*} p<0.1$ The first three columns show results for the full sample, while the remaining columns show results conditional on firm size bins. All regressions control for a third order polynomial in the number of FTE employees in January, awareness of programs at baseline, years of education dummies, gender, age group dummies, firm sector, firm age, country dummies, and the date the survey was completed. The "expectation index" is composed of questions about recovery, future layoffs, and future closure or bankruptcy; the "outcome index" is composed of questions about revenue loss, past layoffs, and permanent closure; and the "approval index" is composed of questions about approval of policies for SMEs, workers, and the government's overall response. See Appendix E for additional details on principal component analysis.

\section{Conclusion}

Though governments in Latin America pledged substantial portions of their GDP to aid small businesses during the COVID-19 crisis, we show that the majority of small firms report very low awareness of and access to programs. This is particularly severe among very small (fewer than five FTE) and informal firms, and those operated by less educated owners. Given the vast predominance of small and informal firms in the region (e.g. McKenzie and Bruhn, 2014; Ulyssea, 2018), our results indicate that policies to aid SMEs had limited reach.

In particular, our results suggest that informality was a key limiting factor. Indeed, our systematization of almost 400 economic and health policies implemented in the region clearly shows that the majority of economic policies for firms had formality as a basic eligibility criterion. In addition, informal firms typically have substantially less access to banks and financial institutions, which further limits their ability to access subsidized loans, the dominant aid policy available in the region.

Beyond informality, our results also suggest that there were obstacles to accessing these policies that hurt smaller firms. The observed gap in awareness levels between smaller and larger firms - which persists at high levels even after conditioning on formality status - can arise for at least three reasons. First, firm sophistication (measured by years of education of the owner), is positively correlated with firm size, and lower sophistication could imply greater difficulties in accessing and processing details about available assistance. Second, larger firms typically have more and better human resources (e.g. accountants or human resources departments), which also contributes to reducing the cost of acquiring information and applying to programs. Third, 
there are fixed costs implied by the application process (e.g. finding a bank that will accept the application and acquiring appropriate documentation of payroll), which are more likely to be binding for smaller businesses.

The results also show that missing out on these programs might have negative consequences for firms regardless of size. We find a sizable and positive association between having access to aid and firms' expectations about survival and layoffs, as well as concrete outcomes such as exit, revenues lost, and layoffs. Firms that receive aid also report higher approval of government programs. Even though we are not able to establish causality, these associations remain even after controlling for a rich set of owner and firm characteristics as well as baseline expectations and awareness.

Finally, our results show that contemporary measures of subjective expectations can be useful indicators of future business outcomes. These measures could be an important tool for policy makers, especially in circumstances when governments have little information about likely outcomes. 


\section{References}

Alfaro, Laura, Oscar Becerra, and Marcela Eslava, "EMEs and COVID-19: Shutting Down in a World of Informal and Tiny Firms," June 2020, (w27360).

Apedo-Amah, Marie Christine, Besart Avdiu, Xavier Cirera, Marcio Cruz, Elwyn Davies, Arti Grover, Leonardo Iacovone, Umut Kilinc, Denis Medvedev, Franklin Okechukwu Maduko, Stavros Poupakis, Jesica Torres, and Trang Thu Tran, "Unmasking the Impact of COVID-19 on Businesses : Firm Level Evidence from across the World," October 2020.

Banerjee, Abhijit, Michael Faye, Alan Krueger, Paul Niehaus, and Tavneet Suri, "Effects of a Universal Basic Income during the pandemic," September 2020, p. 41.

Bartik, Alexander W., Marianne Bertrand, Zoe Cullen, Edward L. Glaeser, Michael Luca, and Christopher Stanton, "How are small businesses adjusting to COVID-19? Early Evidence from a Survey," NBER working paper, 2020, 26989.

Basto-Aguirre, Nathalie, Sebastián Nieto-Parra, and Juan Vázquez-Zamora, "Informality in Latin America in the post COVID-19 era: towards a more formal 'new normal'?," OECD, July 2020.

Bennedsen, Morten, Ian Schmutte, Birthe Larsen, and Daniela Scur, "Preserving job matches during the COVID-19 pandemic: firm-level evidence on the role of government aid," 20202009 , p. 33.

Bottan, Nicolas, Bridget Hoffman, and Diego Vera-Cossio, "Stepping Up During a Crisis: The Unintended Effects of a Noncontributory Pension Program during the Covid-19 Pandemic," IDB Working Paper, November 2020.

$\ldots, \ldots$, and _ , "The unequal impact of the coronavirus pandemic: Evidence from seventeen developing countries," PLoS ONE, October 2020.

Buchheim, Lukas, Carla Krolage, and Sebastian Link, "Sudden Stop: When Did Firms Anticipate the Potential Consequences of Covid-19?," SSRN Scholarly Paper ID 3648797, Social Science Research Network, Rochester, NY July 2020.

Busso, Matías, Juanita Camacho, Julián Messina, and Guadalupe Montengreo, "The Challenge of Protecting Informal Households during the COVID-19 Pandemic: Evidence from Latin America," IDB Discussion Paper, 2020.

Chetty, Raj, John N. Friedman, Nathaniel Hendren, and Michael Stepner, "How Did COVID-19 and Stabilization Policies Affect Spending and Employment? A New Real-Time Economic Tracker Based on Private Sector Data," Working Paper 27431, National Bureau of Economic Research 2020.

Cirera, Xavier, Marcio Cruz, Elwyn Davies, Arti Grover, Leonardo Iacovone, Jose Ernesto Lopez Cordova, Denis Medvedev, Franklin Okechukwu Maduko, Gaurav Nayyar, Santiago Reyes Ortega, and Jesica Torres, "Policies to Support Businesses through the COVID-19 Shock: A Firm Level Perspective," February 2021, p. 33.

Core, Fabrizio and Filippo De Marco, "Public Guarantees for Small Businesses in Italy during Covid-19," Technical Report 15799, C.E.P.R. Discussion Papers February 2021. Publication Title: CEPR Discussion Papers.

Cororaton, Anna and Samuel Rosen, "Public Firm Borrowers of the US Paycheck Protection Program," Working Paper, SSRN 2020. 
Cui, Wei, Jeffrey Hicks, and Max B. Norton, "How Well-Targeted Are Payroll Tax Cuts as a Response to COVID-19? Evidence from China," SSRN Electronic Journal, 2020.

Gamboa, Guadalupe, "Suspensión perfecta de labores tras más de 100 días de cuarentena | Trabajadores | Empleo | Trabajo | MTPE | Ministerio de Trabajo," June 2020. Section: Economía.

Gerard, François, Clément Imbert, and Kate Orkin, "Social protection response to the COVID- 19 crisis: options for developing countries," Oxford Review of Economic Policy, August 2020.

Granja, João, Christos Makridis, Constantine Yannelis, and Eric Zwick, "Did the Paycheck Protection Program Hit the Target?," Working Paper 27095, National Bureau of Economic Research 2020.

Hsieh, Chang-Tai and Benjamin A Olken, "The missing 'missing middle'," 2014.

Humphries, John Eric, Christopher Neilson, and Gabriel Ulyssea, "Information frictions and access to the Paycheck Protection Program," Journal of Public Economics, October 2020 .

IDB, "Micro, Small and Medium-Sized Enterprises," 2020.

IMF, "World Economic Outlook: Managing Divergent Recoveries," 2021.

Kozeniauskas, Nicholas, Pedro Moreira, and Cezar Santos, "Covid-19 and Firms: Productivity and Government Policies," Technical Report 15156, C.E.P.R. Discussion Papers August 2020. Publication Title: CEPR Discussion Papers.

Londoño-Vélez, Juliana and Pablo Querubín, "The Impact of Emergency Cash Assistance in a Pandemic: Experimental Evidence from Colombia," The Review of Economics and Statistics, March 2021, pp. 1-27.

McKenzie, D. and M. Bruhn, "Entry regulation and formalization of microenterprises in developing countries," World Bank Research Observer, 03 2014, 29 (2), 186-201.

OECD, "COVID-19 and the Retail Sector: Impact and Policy Responses," June 2020.

Rahman, Hossain Zillur and Imran Matin, "Livelihoods, Coping and Support During COVID-19 Crisis | Knowledge for policy," 2020.

Ulyssea, Gabriel, "Firms, informality, and development: Theory and evidence from Brazil," American Economic Review, 2018, 108 (8), 2015-47.

_ , "Informality: Causes and consequences for development," Annual Review of Economics, 2020, 12, 525-546.

World Bank, "Global Findex Database 2017: Measuring Financial Inclusion and the Fintech Revolution," 2019. 


\section{A Appendix: COVID-19 policy and data details}

\section{A.1 Policy details}

This subsection provides details on policy data collection and policy design and implementation. We hand-collected and coded information on all major public health policies and economic policies in the eight study countries using official government sources. Table A1 links to these government web pages, as well as general databases we used to cross-check data. Our data reflect the amount of aid pledged by governments between March 11 and August 1, 2020; therefore discrepancies may arise with respect to eventual execution.

Table A2 describes major loan and employment programs while Table A3 describes all cash transfer programs targeted at informal workers. These tables show that the majority of aid expired by late 2020 or early 2021 .

Table A1: Policy sources

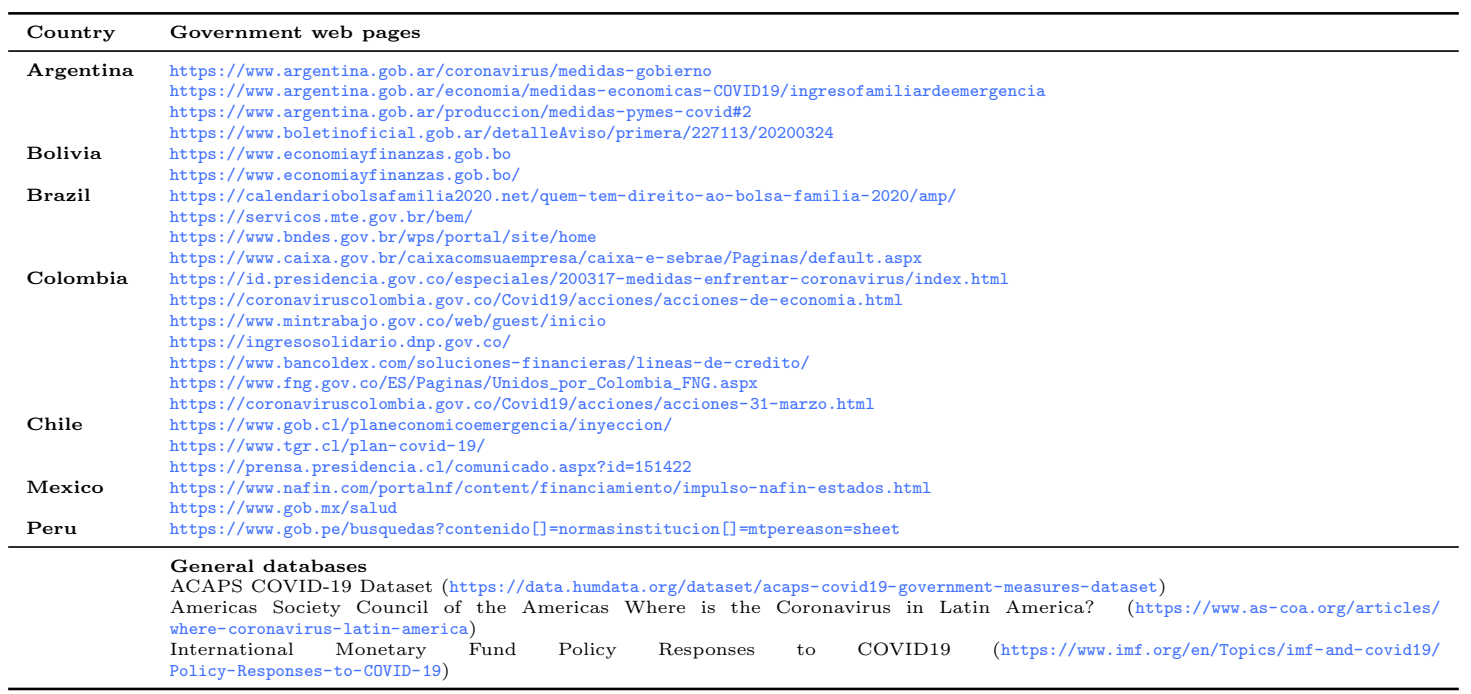


Table A2: Major small business loan and employment programs

\begin{tabular}{|c|c|c|c|c|c|c|c|c|}
\hline \multirow[t]{2}{*}{ Country } & \multirow[t]{2}{*}{ Name and description } & \multicolumn{2}{|c|}{ Loan Programs } & \multicolumn{3}{|c|}{ Employment Programs } & \multirow{2}{*}{ Expiration } & \multirow[t]{2}{*}{$\%$ GDP } \\
\hline & & $\begin{array}{l}\text { Working } \\
\text { capital }\end{array}$ & $\begin{array}{l}\text { Debt } \\
\text { refi- } \\
\text { nancing }\end{array}$ & $\begin{array}{l}\text { Deferred } \\
\text { pay- } \\
\text { ments }\end{array}$ & $\begin{array}{l}\text { Salary } \\
\text { cover- } \\
\text { age }\end{array}$ & $\begin{array}{l}\text { Unemploy } \\
\text { ment } \\
\text { benefits }\end{array}$ & & \\
\hline \multirow[t]{2}{*}{ Argentina } & $\begin{array}{l}\text { Asistencia al Trabajo y la Producción } \\
\text { (ATP): reduction/postponement of em- } \\
\text { ployer contributions, salary paid by the State } \\
\text { for private sector workers, unemployment } \\
\text { benefits }\end{array}$ & & & $\checkmark$ & $\checkmark$ & $\checkmark$ & $\begin{array}{l}\text { 2021-01-10 } \\
\text { (extended } \\
\text { monthly) }\end{array}$ & $.30 \%$ \\
\hline & $\begin{array}{l}\text { Fondo de Garantías Argentino } \\
\text { (FOGAR): tax exemption for bank } \\
\text { loans and debts, financing for SMEs }\end{array}$ & $\checkmark$ & $\checkmark$ & & & & 2021-03-20 & $.70 \%$ \\
\hline \multirow[t]{2}{*}{ Bolivia } & $\begin{array}{l}\text { Programa Especial de Apoyo a La Mi- } \\
\text { cro, Pequeña y Mediana Empresa: five- } \\
\text { year loans to safeguard employment }\end{array}$ & $\checkmark$ & & & & & Ongoing & $0.50 \%$ \\
\hline & $\begin{array}{l}\text { Plan de Emergencia de Apoyo al Em- } \\
\text { pleo y Estabilidad Laboral: credits equiv- } \\
\text { alent to two national minimum wages, per } \\
\text { worker, per month, for a maximum of two } \\
\text { months }\end{array}$ & & & $\checkmark$ & & $\checkmark$ & 2020-09-16 & $0.66 \%$ \\
\hline \multirow[t]{4}{*}{ Brazil } & $\begin{array}{l}\text { Programa Emergencial de Acesso a } \\
\text { Crédito (PEAC): guarantee program for } \\
\text { SMEs that reduced the risk of default for the } \\
\text { credit granting financial institutions }\end{array}$ & $\checkmark$ & $\checkmark$ & & & & $2020-12-31$ & $0.07 \%$ \\
\hline & $\begin{array}{l}\text { Programa Emergencial de Manutenção } \\
\text { do Emprego e da Renda: employment } \\
\text { program supporting works with suspended } \\
\text { employment contracts or reduced hours, pro- } \\
\text { vides benefit equivalent to what worker } \\
\text { would have received as unemployment insur- } \\
\text { ance }\end{array}$ & & & & & $\checkmark$ & $2020-12-31$ & $0.71 \%$ \\
\hline & $\begin{array}{l}\text { Programa Emergencial de Suporte a } \\
\text { Empregos: loans for SMEs to over payroll } \\
\text { for up to } 4 \text { months }\end{array}$ & $\checkmark$ & & & & & $2020-10-31$ & $0.47 \%$ \\
\hline & $\begin{array}{l}\text { Credit Lines from SMEs from Caixa } \\
\text { Econômica Federal and Sebrae: loans } \\
\text { from state-owned banks for SMEs to cover } \\
\text { working capital }\end{array}$ & $\checkmark$ & & & & & Ongoing & $0.10 \%$ \\
\hline \multirow[t]{2}{*}{ Chile } & $\begin{array}{l}\text { Fondo de Garantías para Pequeños Em- } \\
\text { presarios (FOGAPE): credit line which in- } \\
\text { cludes working capital credits equivalent to } \\
\text { three months of sales }\end{array}$ & $\checkmark$ & $\checkmark$ & & & & $\begin{array}{l}\text { Until funds } \\
\text { run out }\end{array}$ & $9.8 \%$ \\
\hline & $\begin{array}{l}\text { Ley de Protección al Empleo: series } \\
\text { of laws which prevents companies from fir- } \\
\text { ing workers due to COVID-19 and provides } \\
\text { benefits to unemployed and underemployed } \\
\text { workers }\end{array}$ & & & & $\checkmark$ & & 2021-12-21 & $? \%$ \\
\hline \multirow[t]{3}{*}{ Colombia } & $\begin{array}{l}\text { Colombia Responde: loans for businesses } \\
\text { in tourist, air transport and entertainment } \\
\text { sectors. }\end{array}$ & $\checkmark$ & $\checkmark$ & & & & $\begin{array}{l}\text { Until funds } \\
\text { run out }\end{array}$ & $.02 \%$ \\
\hline & $\begin{array}{l}\text { Colombia Responde Para Todos: loans } \\
\text { for businesses in all sectors besides agricul- } \\
\text { ture }\end{array}$ & $\checkmark$ & $\checkmark$ & & & & $\begin{array}{l}\text { Until funds } \\
\text { run out }\end{array}$ & $.03 \%$ \\
\hline & $\begin{array}{l}\text { Unidos por Colombia: special guaran- } \\
\text { tee program for all businesses impacted by } \\
\text { COVID-19. }\end{array}$ & $\checkmark$ & $\checkmark$ & & & & $\begin{array}{l}\text { Until funds } \\
\text { run out }\end{array}$ & $.98 \%$ \\
\hline \multirow[t]{2}{*}{ Dominican Republic } & $\begin{array}{l}\text { Loans from Central Bank: short term liq- } \\
\text { uidity for SMEs }\end{array}$ & $\checkmark$ & & & & & $\begin{array}{l}\text { Until funds } \\
\text { run out }\end{array}$ & $.30 \%$ \\
\hline & $\begin{array}{l}\text { Fondo de Apoyo Solidario al Empleado } \\
\text { I y II: employment protection program for } \\
\text { SMEs which includes unemployment benefits } \\
\text { and salary contributions }\end{array}$ & & & & $\checkmark$ & $\checkmark$ & 2020-07-01 & $.30 \%$ \\
\hline \multirow[t]{4}{*}{ Mexico } & $\begin{array}{l}\text { Medidas de Protección y Apoyo: Unem- } \\
\text { ployment insurance for up to three months; } \\
\text { deferral of monthly payments, payroll sup- } \\
\text { port membership }\end{array}$ & & & $\checkmark$ & $\checkmark$ & $\checkmark$ & $2020-07-30$ & $0.08 \%$ \\
\hline & $\begin{array}{l}\text { Crédito ISSSTE: Loans to support re- } \\
\text { tirees, pensioners, and workers affiliated } \\
\text { with ISSSTE }\end{array}$ & $\checkmark$ & & & & & 2020-05-05 & $.14 \%$ \\
\hline & $\begin{array}{l}\text { Créditos Solidarios a Palabra: Loans for } \\
\text { domestic workers and independent workers }\end{array}$ & & $\checkmark$ & & & & 2020-06-15 & $.02 \%$ \\
\hline & $\begin{array}{l}\text { Tandas de Bienestar: Loans for SMES } \\
\text { who have been excluded from traditional fi- } \\
\text { nancial services }\end{array}$ & & $\checkmark$ & & & & Ongoing & $.01 \%$ \\
\hline \multirow[t]{3}{*}{ Peru } & $\begin{array}{l}\text { Reactiva Perú: extensive loan program for } \\
\text { small, medium, and large businesses across } \\
\text { many sectors }\end{array}$ & $\checkmark$ & $\checkmark$ & & & & $2020-11-30$ & $8.11 \%$ \\
\hline & $\begin{array}{l}\text { Suspensión Perfecta de Labores: liquid- } \\
\text { ity equivalent to monthly compensation for } \\
\text { workers not working or laid off as a result of } \\
\text { COVID-19 }\end{array}$ & & & & $\checkmark$ & & 2021-05-05 & $0.01 \%$ \\
\hline & $\begin{array}{l}\text { Fondo de Apoyo Empresarial para } \\
\text { MYPEs (FAE-MYPE): creation of guar- } \\
\text { antee fund for loans to SMEs }\end{array}$ & $\checkmark$ & $\checkmark$ & & & & $2020-12-31$ & $0.04 \%$ \\
\hline
\end{tabular}


Table A3: Cash transfer programs targeted at informal workers

\begin{tabular}{|c|c|c|c|c|c|}
\hline Country & Name & Description & Automatic? & Expiration & $\%$ GDP \\
\hline Argentina & Ingreso Familiar de Emergencia (IFE) & $\begin{array}{l}\text { Transfer for households with a household } \\
\text { head between } 18 \text { and } 65 \text { who works in do- } \\
\text { mestic service, is an informal worker, is a } \\
\text { monostributista social (categories A and B), } \\
\text { or households receiving AUH or Progresar } \\
\text { social programs; household must not have a } \\
\text { formal source of labor income or receive any } \\
\text { pensions. }\end{array}$ & Yes & $2020-08-31$ & $0.21 \%$ \\
\hline \multirow[t]{2}{*}{ Bolivia } & Bono Universal & $\begin{array}{l}\text { For adults between ages } 18 \text { and } 60 \text { who } \\
\text { do not receive any other government trans- } \\
\text { fers (for retirement, widowhood, disability or } \\
\text { meritorious), nor wages from public or pri- } \\
\text { vate institutions, nor pensions or rents. }\end{array}$ & Yes & $2020-08-21$ & $0.45 \%$ \\
\hline & Bono Canasta Familiar (BCF) & $\begin{array}{l}\text { For current beneficiaries of social assistance } \\
\text { programs who are not formal workers. }\end{array}$ & Yes & $2020-08-21$ & $0.16 \%$ \\
\hline Brazil & Auxilio Emergencial & $\begin{array}{l}\text { Transfer for households with a single mother } \\
\text { as household head, or with individuals whose } \\
\text { main source of income comes from being } \\
\text { informal workers or self-employed; unem- } \\
\text { ployed; or microentrepeneurs; these house- } \\
\text { holds must not be beneficiaries of Bolsa Fa- } \\
\text { milia. }\end{array}$ & No & 2021-01-27 & $1.35 \%$ \\
\hline \multirow[t]{2}{*}{ Chile } & Ingreso Familiar de Emergencia & $\begin{array}{l}\text { Transfer for households whose source of in- } \\
\text { come is mainly from informal sources. The } \\
\text { amount depends on the number of people in } \\
\text { the household and decreases according to the } \\
\text { percentage of income that is formal; pension- } \\
\text { ers from Pension Solidaria de la Vejez receive } \\
\text { a smaller amount of aid. }\end{array}$ & No & 2021-09-07 & $0.15 \%$ \\
\hline & Bono de Emergencia COVID-19 & $\begin{array}{l}\text { Households with individuals receiving Sub- } \\
\text { sidio Familiar (SUF), households in the } \\
\text { Sistema de Seguridades y Oportunidades } \\
\text { database, households who belong to the } 60 \% \\
\text { most vulnerable according to the Registro } \\
\text { Social de Hogares database, and households } \\
\text { who do not have a formal income through } \\
\text { employment or pension and do not have any } \\
\text { SUF beneficiaries. This totals to around } 3 \\
\text { million households. }\end{array}$ & Yes & 2020-04-30 & $0.08 \%$ \\
\hline Colombia & Ingreso Solidario & $\begin{array}{l}\text { Households under extreme poverty, poverty, } \\
\text { or economic vulnerability that do not re- } \\
\text { ceive any social program (Familias en accion, } \\
\text { Jovenes en accion, Colombia Mayor) but be- } \\
\text { long to SISBEN. }\end{array}$ & Yes & $2020-11-15$ & $0.04 \%$ \\
\hline \multirow[t]{2}{*}{ Dominican Republic } & Quedáte en Casa & $\begin{array}{l}17 \text { billion Dominican pesos in cash transfers } \\
\text { to vulnerable households, including informal } \\
\text { workers }\end{array}$ & Yes & 2021-05-01 & $0.34 \%$ \\
\hline & Pa'ti & $\begin{array}{l}\text { Pa'ti is introduced to support independent } \\
\text { workers, providing RD } 5,000 \text { a month to each } \\
\text { beneficiary in May and June. }\end{array}$ & Yes & $2020-12-31$ & $0.05 \%$ \\
\hline Peru & Bono YoMeQuedoEnCasa & $\begin{array}{l}\text { Cash transfer of } 380 \text { PEN (later extended to } \\
760 \text { ) for poor families }\end{array}$ & Yes & $\begin{array}{l}30 \text { days post- } \\
\text { pandemic }\end{array}$ & $0.16 \%$ \\
\hline
\end{tabular}

\section{A.2 COVID-19 data details}

Our data on COVID-19 cases, deaths, and government stringency data come from Our World in Data (https://ourworldindata.org/coronavirus), which is compiled from several sources:

- Confirmed cases and deaths: these data come from the COVID-19 Data Repository by the Center for Systems Science and Engineering at Johns Hopkins University. Important to note is that the number of cases or deaths reported on a given day does not necessarily represent the actual number on that date because of the long reporting chain that exists between a new case/death and its inclusion in statistics. In addition, the reported numbers of cases and deaths can be strongly affected by testing capacity and reporting policy.

- Government stringency: these data come from the Oxford COVID-19 Government Response Tracker from the Blavatnik School of Government. The stringency index records the strictness of 'lockdown style' policies that primarily restrict people's behaviour. It is calculated using all ordinal containment and closure policy indicators, plus an indicator recording public information campaigns.

\section{A.2.1 Excess mortality}

Given the limitations of raw mortality and cases data, we also consider how excess mortality relates to COVID-19 deaths in each study country. Many consider excess mortality to be a more 
objective indicator of the COVID-19 death toll because it captures not only confirmed deaths, but also COVID-19 deaths that were not correctly diagnosed and reported, as well as deaths from other causes.

Figure A1 compares the number of cumulative excess deaths in 2020 to the cumulative number of COVID-19 related deaths in May and July. In each country besides Argentina, cumulative excess deaths are greater than cumulative COVID-19 related deaths. 
Figure A1: Cumulative excess deaths compared to cumulative COVID-19 related deaths
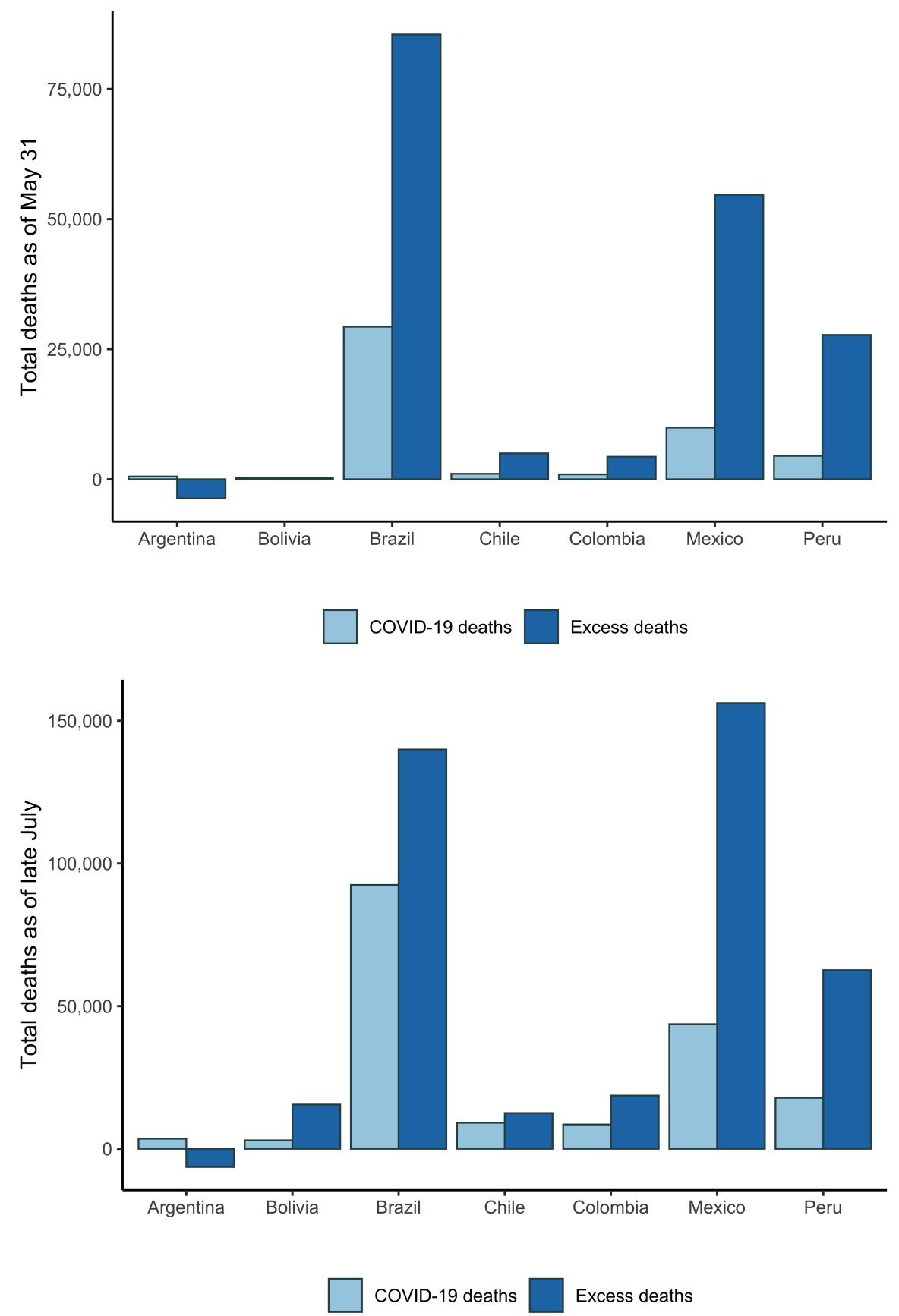

Note: Based on Human Mortality Database (2021) and the World Mortality Database (2021). The top figure compares total deaths as of May 31. The bottom figure compares total deaths as of late July. Excess death data is estimated monthly in Argentina, Bolivia, and Brazil. It is estimated weekly for Colombia, Mexico, Peru, and Chile. For this reason, for Colombia, Mexico, Peru, and Chile, we show total deaths as of July 28. For Argentina, Bolivia, and Brazil, we show total deaths as of July 31. 


\section{B Appendix: Survey details}

Participants were recruited via Facebook advertisements targeted at business owners in eight countries in the Latin American region: Argentina, Bolivia, Brazil, Colombia, Dominican Republic, Mexico, and Peru. Figure B1 provides a photo of the advertisements used for recruiting for the survey. Advertisements were targeted at people living aged 25 or older, and targeted people who matched:

- Behaviors: Small business owners

- Employers: Business Owner

- Interests: Small Business

- Job title: Owner and Founder

Figure B1: Facebook advertisement used for recruitment

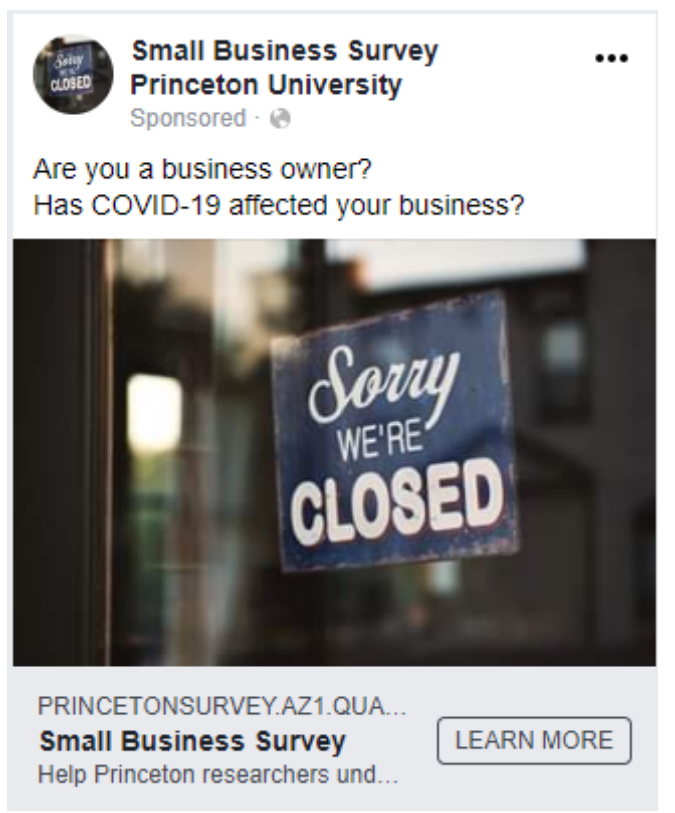

We used four instruments in the study:

- A short version of the baseline survey, which was used from March 29 to April 19, 2020 in the eight study countries

- A long version of the baseline survey, which was used from April 19 to May 31, 2020

- A first follow-up survey, the "July Follow-Up", which was used from June 25 to August 16,2020

- A second follow-up survey, the "November Follow-Up", which was used from November 5 to December 20, 2020.

There were two versions of the baseline survey. The short baseline survey, distributed through Facebook, was completed by respondents across the eight countries in the study. On April 19, 2020, we emailed respondents who had completed the short baseline survey and requested they complete a longer version of the survey which repeated questions about employment and expectations, and included a broader set of questions with a particular focus on respondents' access to programs. For respondents who answered both versions of the survey, we report 
respondents' answers to the longer survey. ${ }^{28}$ We stopped distributing the short version while we distributed this longer version to second-time respondents, hence the gap in new intake from April 19 to May 9, 2020. On May 9, 2020, we started distributing the longer version on Facebook in six of the eight study countries.

The follow-up surveys repeated questions about employment, expectations, and access to aid, and included a comprehensive set of questions about business outcomes. Our first follow-up was completed by 2,452 business owners and the second follow-up was completed by 1,549 firm owners.

${ }^{28}$ This also allows us a cover a longer time period. 


\section{Appendix: Details on survey respondents}

This section provides details on survey respondents, with a focus on the large baseline intake. Figure $\mathrm{C} 1$ shows the geographic distribution of respondents across the Latin American region at baseline. We had the greatest number of respondents in Mexico and Colombia. Table C1 shows the number of respondents in each week of the survey while Table C2 provides summary statistics for key variables. Figure $\mathrm{C} 2$ shows the relative firm size and formality distribution across weeks of the survey. Firm size and formality distribution remained relatively consistent over the sampling period, though there was a slight decrease in the share of informal and small firm owners in the last two weeks of the survey.

Figures $\mathrm{C} 3$ and $\mathrm{C} 4$ show the firm size and formality distribution of survey respondents compared to secondary data. Overall, firm size distribution in our survey is similar to the firm size distribution in administrative data from each country. We moderately overestimate the share of formal employees compared to the share of formal workers in the workforce of each country according to the International Labor Organization (ILO). However, there are several limitations to this comparison. First, while there is data on what proportion of the labor force is informal, there is typically no data on the proportion of small businesses that are informal. We use the share of informal employment out of total employment as a proxy, but it is not directly comparable. Second, we only have information of formality for 8,196 out of 34,403 firms in our sample. ${ }^{29}$

\footnotetext{
${ }^{29}$ We only had the informality question in the long version of the survey, which reached significantly fewer firm owners. As a result, we only have the informality question answered for a) the majority of firm owners who received the long baseline survey, and b) some firm owners who received the short version but answered the informality question in subsequent follow ups.
} 
Figure C1: Distribution of baseline survey across Latin America

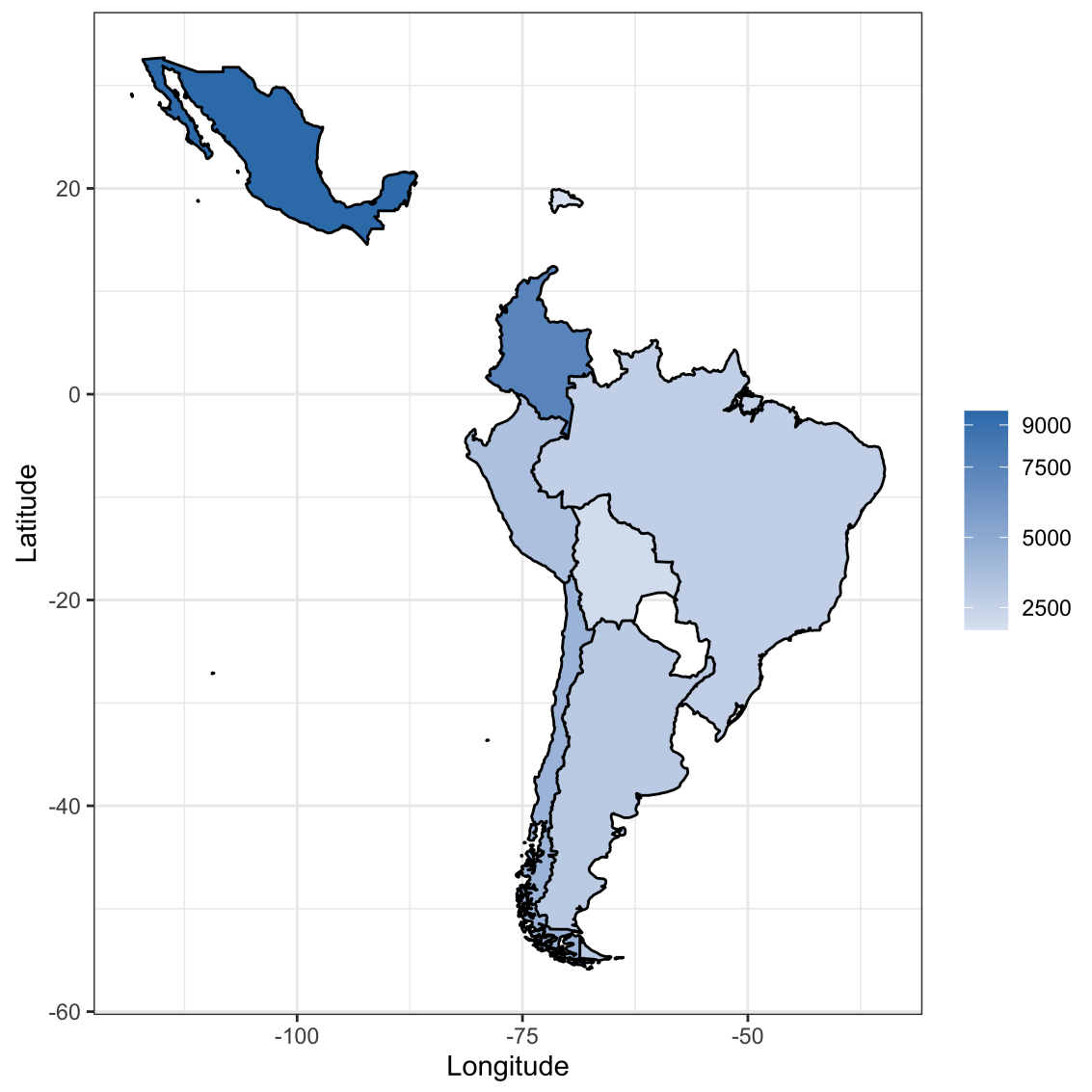

Note: Figure shows number of valid survey responses by country for the baseline survey. 
Table C1: Valid survey responses by week

\begin{tabular}{|c|c|}
\hline Week & $\mathrm{N}$ \\
\hline \multicolumn{2}{|c|}{ Baseline survey } \\
\hline $2020-03-29-2020-03-31$ & 3,730 \\
\hline 2020-04-01 - 2020-04-07 & 13,306 \\
\hline 2020-04-08 - 2020-04-14 & 4,007 \\
\hline 2020-04-15 - 2020-04-21 & 3,051 \\
\hline $2020-04-22-2020-04-28$ & 2,016 \\
\hline $2020-04-29-2020-05-05$ & 981 \\
\hline 2020-05-06 - 2020-05-12 & 3,872 \\
\hline 2020-05-13 - 2020-05-19 & 3,117 \\
\hline $2020-05-20-2020-05-26$ & 272 \\
\hline 2020-05-27 - 2020-05-31 & 51 \\
\hline \multicolumn{2}{|c|}{ July follow up } \\
\hline $2020-06-25-2020-06-30$ & 404 \\
\hline 2020-07-01 - 2020-07-07 & 463 \\
\hline 2020-07-08 - 2020-07-14 & 484 \\
\hline 2020-07-15 - 2020-07-21 & 258 \\
\hline $2020-07-22-2020-07-28$ & 655 \\
\hline 2020-07-29 - 2020-08-04 & 128 \\
\hline 2020-08-05 - 2020-08-10 & 56 \\
\hline 2020-08-12 - 2020-08-16 & 4 \\
\hline \multicolumn{2}{|c|}{ November follow up } \\
\hline $2020-11-05-2020-11-10$ & 434 \\
\hline $2020-11-11-2020-11-17$ & 250 \\
\hline 2020-11-18 - 2020-11-24 & 424 \\
\hline $2020-11-25-2020-12-01$ & 260 \\
\hline 2020-12-02 - 2020-12-07 & 73 \\
\hline 2020-12-09 - 2020-12-14 & 3 \\
\hline $2020-12-16-2020-12-20$ & 105 \\
\hline
\end{tabular}

Note: Table shows number of valid survey responses by week. 
Table C2: Descriptive statistics

\begin{tabular}{|c|c|c|c|c|c|c|c|c|c|}
\hline & \multicolumn{3}{|c|}{ Baseline } & \multicolumn{3}{|c|}{ July follow up } & \multicolumn{3}{|c|}{ November follow up } \\
\hline & Mean & $\mathrm{SD}$ & $\mathrm{N}$ & Mean & $\mathrm{SD}$ & $\mathrm{N}$ & Mean & $\mathrm{SD}$ & $\mathrm{N}$ \\
\hline Jan. FTE employees & 6.83 & 11.65 & 34,403 & 7.11 & 11.95 & 2,452 & 7.46 & 12.40 & 1,549 \\
\hline Informal firm & 0.31 & 0.46 & 8,196 & 0.26 & 0.44 & 1,808 & 0.29 & 0.45 & 1,482 \\
\hline Sector: Manufacturing & 0.04 & 0.19 & 7,840 & 0.04 & 0.20 & 1,765 & 0.04 & 0.19 & 1,147 \\
\hline Sector: Construction & 0.05 & 0.22 & 7,840 & 0.05 & 0.22 & 1,765 & 0.06 & 0.23 & 1,147 \\
\hline Sector: Retail & 0.35 & 0.48 & 7,840 & 0.32 & 0.47 & 1,765 & 0.33 & 0.47 & 1,147 \\
\hline Sector: Services & 0.38 & 0.49 & 7,840 & 0.40 & 0.49 & 1,765 & 0.39 & 0.49 & 1,147 \\
\hline Sector: Other & 0.18 & 0.38 & 7,840 & 0.19 & 0.39 & 1,765 & 0.18 & 0.39 & 1,147 \\
\hline Firm age & 9.15 & 10.17 & 7,810 & 9.07 & 9.99 & 1,760 & 8.54 & 8.97 & 1,140 \\
\hline Years of education & 14.63 & 2.23 & 7,932 & 14.87 & 2.17 & 1,771 & 14.96 & 2.12 & 1,151 \\
\hline Female & 0.44 & 0.50 & 7,424 & 0.42 & 0.49 & 1,680 & 0.43 & 0.50 & 1,109 \\
\hline Age Group: $18-24$ & 0.02 & 0.14 & 7,930 & 0.01 & 0.12 & 1,771 & 0.01 & 0.11 & 1,150 \\
\hline Age Group: $25-34$ & 0.25 & 0.43 & 7,930 & 0.21 & 0.40 & 1,771 & 0.21 & 0.41 & 1,150 \\
\hline Age Group: 35 - 49 & 0.53 & 0.50 & 7,930 & 0.55 & 0.50 & 1,771 & 0.53 & 0.50 & 1,150 \\
\hline Age Group: $50+$ & 0.21 & 0.40 & 7,930 & 0.23 & 0.42 & 1,771 & 0.24 & 0.43 & 1,150 \\
\hline Already laid off workers & 0.58 & 0.49 & 33,307 & 0.54 & 0.50 & 2,441 & 0.65 & 0.48 & 1,389 \\
\hline Expect to lay off workers & 0.62 & 0.48 & 30,177 & 0.51 & 0.50 & 1,294 & 0.33 & 0.47 & 1,196 \\
\hline Recover two years & 0.68 & 0.47 & 28,763 & 0.77 & 0.42 & 2,097 & 0.74 & 0.44 & 1,330 \\
\hline Expect to recover ever & 0.92 & 0.27 & 28,683 & 0.96 & 0.21 & 2,186 & 0.95 & 0.23 & 1,328 \\
\hline Aware of programs & 0.27 & 0.44 & 28,815 & 0.46 & 0.50 & 1,667 & 0.47 & 0.50 & 1,474 \\
\hline Aware of programs to cover wages & 0.12 & 0.32 & 26,932 & 0.35 & 0.48 & 1,382 & & & \\
\hline Aware of subsidized loans & 0.15 & 0.35 & 26,932 & 0.40 & 0.49 & 1,382 & & & \\
\hline Expected prob. of bankruptcy & 0.50 & 0.28 & 27,608 & 0.37 & 0.30 & 2,189 & 0.25 & 0.30 & 307 \\
\hline Closed & 0.09 & 0.29 & 10,359 & 0.06 & 0.24 & 2,442 & 0.07 & 0.25 & 1,535 \\
\hline Applied & 0.16 & 0.36 & 8,514 & 0.43 & 0.50 & 2,191 & 0.40 & 0.49 & 1,475 \\
\hline Perc. revenue loss & 69.20 & 24.63 & 6,780 & 68.60 & 26.26 & 1,305 & 70.96 & 25.33 & 1,416 \\
\hline Approve of policies for SMEs & 0.33 & 0.47 & 4,588 & 0.30 & 0.46 & 1,269 & 0.27 & 0.44 & 1,256 \\
\hline Approve of policies for workers & 0.43 & 0.49 & 4,588 & 0.41 & 0.49 & 1,269 & 0.37 & 0.48 & 1,256 \\
\hline Gov. reaction was appropriate & 0.43 & 0.50 & 4,556 & 0.31 & 0.46 & 1,266 & 0.29 & 0.45 & 1,245 \\
\hline Received help & 0.05 & 0.21 & 3,184 & 0.17 & 0.38 & 1,992 & 0.20 & 0.40 & 1,470 \\
\hline
\end{tabular}

Notes: We restrict the analysis to businesses with fewer than $150 \mathrm{FTE}$ employees, and we only include respondents who complete at least the first question regarding employment in January. The first panel shows firm characteristics, the second panel shows firm owners' characteristics, and the third panel shows outcomes. The baseline questions with lower observations counts were only asked in the extended baseline survey. Not all respondents complete the entire survey. 
Figure C2: Firm size and formality across weeks of the survey
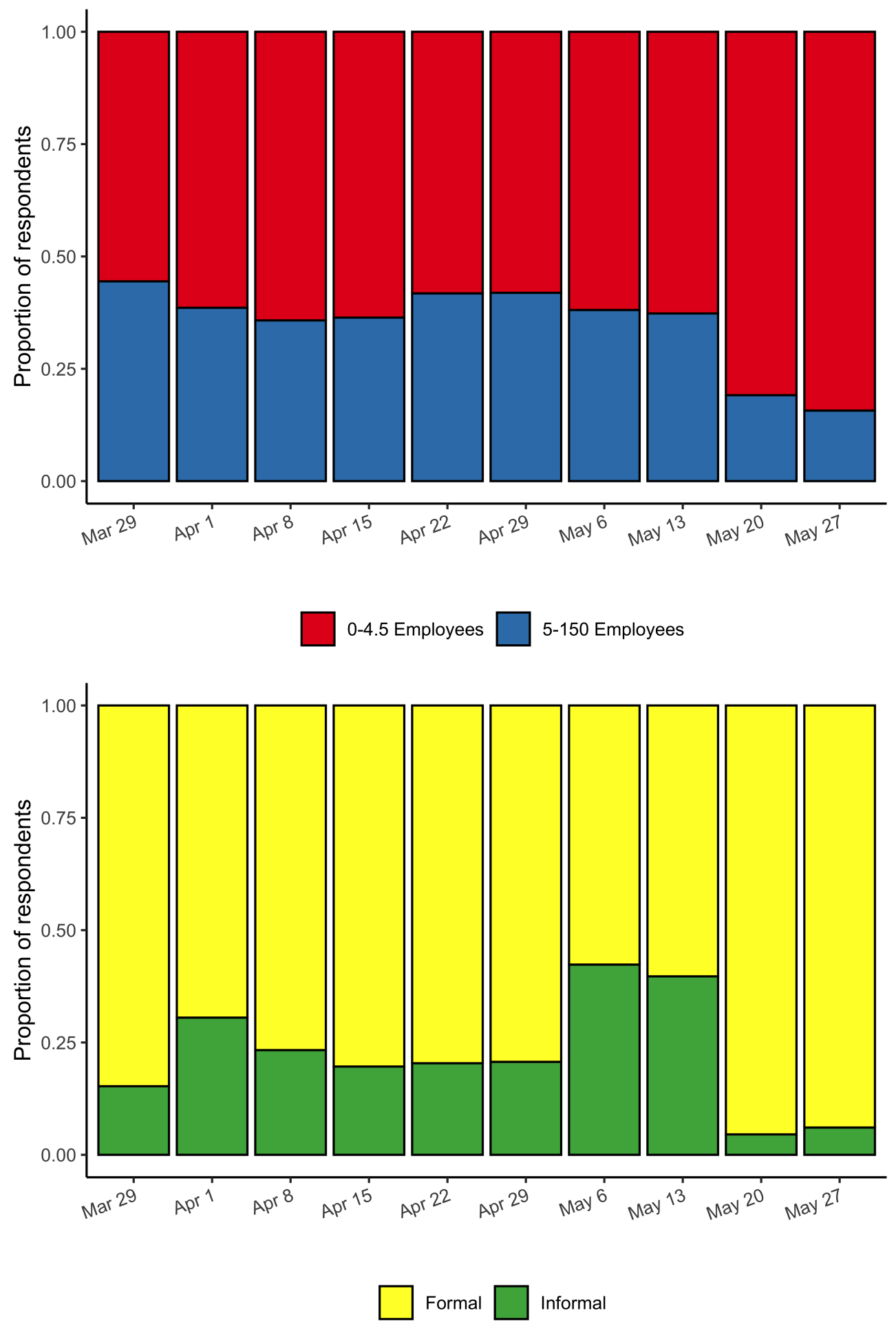

Note: The top panel shows the proportion of weekly respondents in two size bins based on their FTE employment in January (0-4.5 employees, 5-150 employees). The bottom panels shows the proportion of weekly respondents who owned informal or formal businesses. Dates correspond to the week of the baseline survey. 
Figure C3: Firm size distribution: survey compared to administrative data
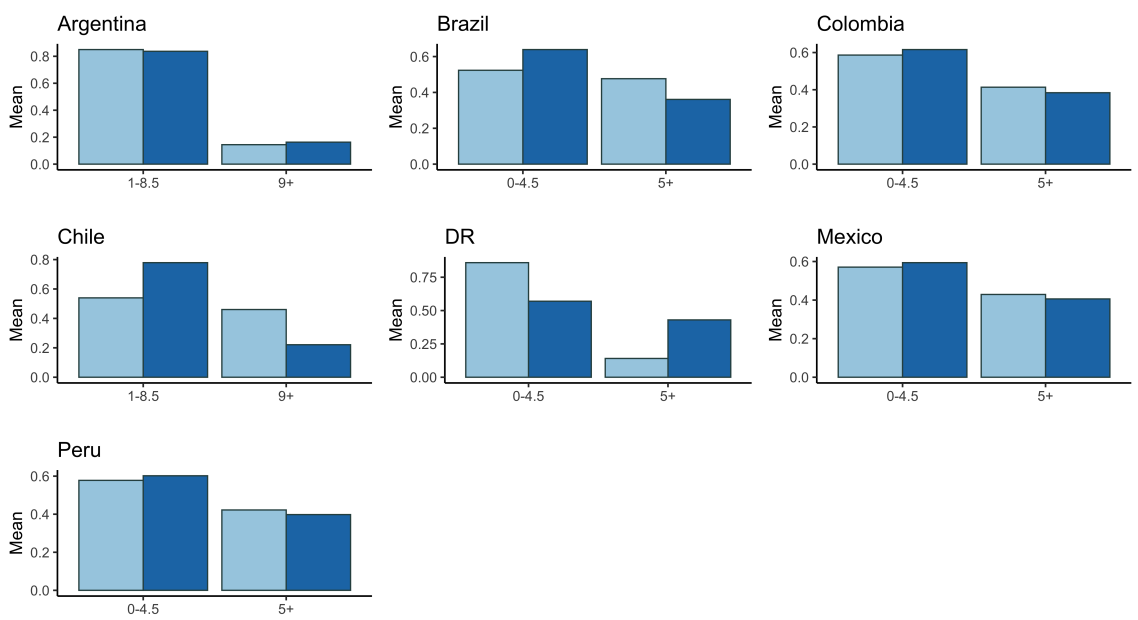

$\square$ Admin data

Survey

Notes: Figure shows the share of firms with fewer than 150 employees in each employment category in country's administrative data (in light blue) and the survey respondents (in dark blue). Official employment data for Argentina and Chile was only available in the 1-8.5 bin and 9-150 bin. Administrative data on distribution of firm size was not available in Bolivia.

Figure C4: Share of formal workers: survey compared to ILO data
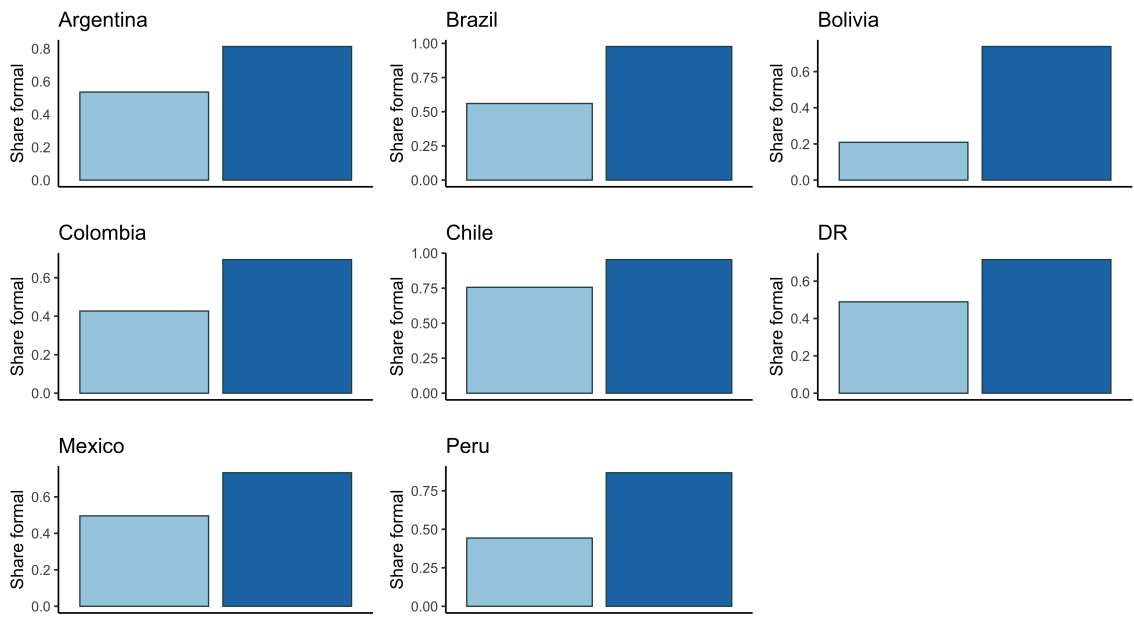

Notes: Figure shows the share of formal workers in the workforce of each country according to the International Labor Organization (ILO) (in light blue) and the share of formal employees in the survey (in dark blue). We construct the share of formal employees by assuming all employees of a formal firm are formal, and all employees of an informal firm are informal. The data contain formality information for 8,196 out of 34,403 firms.

\section{Appendix: Trends over time}

This section provides additional results on the evolution of expectations and awareness in the early months of the pandemic. Table D1 is a table version of Figure 2 from the paper. Figure D1 shows the evolution of awareness by type of program and firm size. The top panel shows that less than 50 percent of firm owners were aware of any programs to help their business, while even fewer were aware of programs that covered wages or offered subsidized loans. The 
bottom panel shows that there were substantial gaps in awareness across firm size bins at the beginning of the pandemic, as well as marked differences in their evolution over the first three weeks. Businesses with more than five employees were substantially more aware of programs from the onset, and learned about programs more quickly than smaller firms. Tables D2 and D3 are a table versions of Figure D1.

Table D1: Trends in expectations in first three months of pandemic

\begin{tabular}{lcccccc}
\hline & Recover two years & Recover ever & Prob. bankrupt & Expect future layoffs & Past layoffs & Prop of Jan workers working \\
\hline Week of March 29 & $0.812^{* * *}$ & $0.941^{* * *}$ & $0.316^{* * *}$ & $0.383^{* * *}$ & $0.215^{* * *}$ & $0.971^{* * *}$ \\
& $(0.070)$ & $(0.028)$ & $(0.046)$ & $(0.083)$ & $(0.078)$ & $(0.065)$ \\
Week of April 1 & $0.769^{* * *}$ & $0.936^{* * *}$ & $0.349^{* * *}$ & $0.396^{* * *}$ & $0.329^{* * *}$ & $0.837^{* * *}$ \\
& $(0.069)$ & $(0.027)$ & $(0.045)$ & $(0.082)$ & $(0.077)$ & $(0.064)$ \\
Week of April 8 & $0.749^{* * *}$ & $0.928^{* * *}$ & $0.370^{* * *}$ & $0.400^{* * *}$ & $0.388^{* * *}$ & $0.771^{* * *}$ \\
& $(0.069)$ & $(0.027)$ & $(0.045)$ & $(0.082)$ & $(0.078)$ & $(0.064)$ \\
Week of April 15 & $0.696^{* * *}$ & $0.919^{* * *}$ & $0.380^{* * *}$ & $0.417^{* * *}$ & $0.401^{* * *}$ & $0.759^{* * *}$ \\
& $(0.069)$ & $(0.027)$ & $(0.045)$ & $(0.082)$ & $(0.078)$ & $(0.064)$ \\
Week of May 6 & $0.797^{* * *}$ & $0.965^{* * *}$ & $0.323^{* * *}$ & $0.349^{* * *}$ & $0.383^{* * *}$ & $0.828^{* * *}$ \\
& $(0.069)$ & $(0.027)$ & $(0.046)$ & $(0.083)$ & $(0.078)$ & $(0.064)$ \\
Week of May 13 & $0.772^{* * *}$ & $0.967^{* * *}$ & $0.325^{* * *}$ & $0.332^{* * *}$ & $0.422^{* * *}$ & $0.802^{* * *}$ \\
& $(0.069)$ & $(0.027)$ & $(0.045)$ & $(0.082)$ & $(0.078)$ & $(0.064)$ \\
$N$ & 25,085 & 25,007 & 23,971 & 26,727 & 29,387 & 25,830
\end{tabular}

Notes: ${ }^{* * *} p<0.01,{ }^{* *} p<0.05,{ }^{*} p<0.1$ Note: Table shows results from baseline survey between March 29th and May 19th. The weeks of May 20th and May 27th are omitted. All regressions control for a third order polynomial in the number of full-time equivalent employees in January, country dummies, years of education dummies, gender, age group dummies, firm sector, and firm age. Decreasing sample size is a result of within-survey attrition.

Figure D1: "Are you aware of any state or federal programs that could help your business?"

(a) By program type

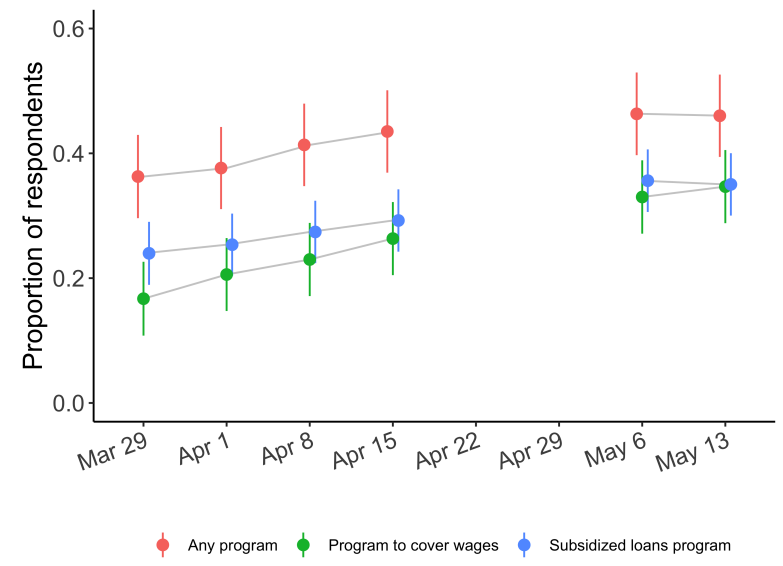

(b) By firm size

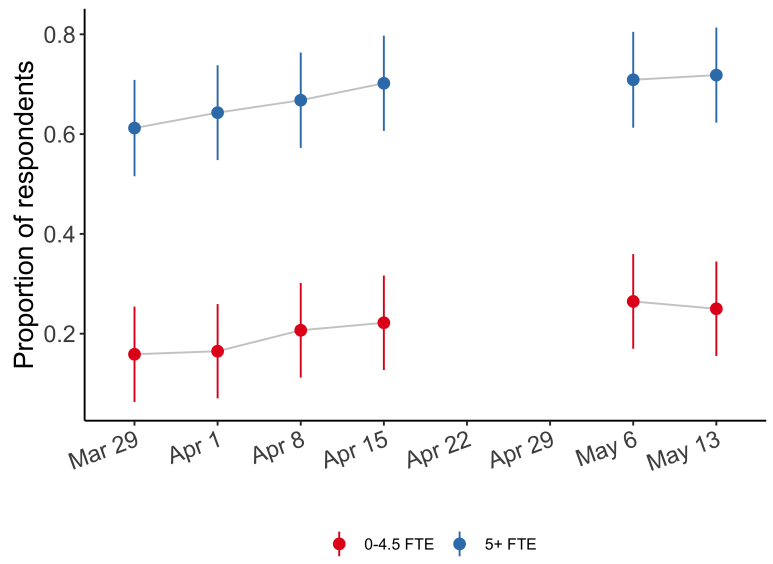

Note: Figure shows results from baseline survey between March 29th and May 19th. The weeks of May 20th and May 27 th are omitted. All regressions control for a third order polynomial in the number of full-time equivalent employees in January, the day of the week the survey was completed, awareness of programs at baseline, years of education dummies, gender, age group dummies, firm sector, firm age, country dummies, and the date the survey was completed. The omitted group for country is Argentina. The omitted group for firm owner age group is 35-39 years old. See Table D2 for a table version of panel (a) and Table D3 for a table version of panel (b). 
Table D2: Trends in awareness in first three months of pandemic

\begin{tabular}{|c|c|c|c|}
\hline & Aware of programs & Aware of subsidized loans & Aware of programs to cover wages \\
\hline \multirow[t]{2}{*}{ Week of March 29} & $0.363^{* * *}$ & $0.167^{* *}$ & $0.240^{* * *}$ \\
\hline & $(0.077)$ & $(0.070)$ & $(0.067)$ \\
\hline \multirow{2}{*}{ Week of April 1} & $0.376^{* * *}$ & $0.206^{* * *}$ & $0.254^{* * *}$ \\
\hline & $(0.076)$ & $(0.069)$ & $(0.067)$ \\
\hline \multirow[t]{2}{*}{ Week of April 8} & $0.414^{* * *}$ & $0.230^{* * *}$ & $0.274^{* * *}$ \\
\hline & $(0.076)$ & $(0.069)$ & $(0.067)$ \\
\hline \multirow[t]{2}{*}{ Week of April 15} & $0.435^{* * *}$ & $0.263^{* * *}$ & $0.292^{* * *}$ \\
\hline & $(0.076)$ & $(0.069)$ & $(0.067)$ \\
\hline \multirow[t]{2}{*}{ Week of May 6} & $0.463^{* * *}$ & $0.330^{* * *}$ & $0.356^{* * *}$ \\
\hline & $(0.076)$ & $(0.069)$ & $(0.067)$ \\
\hline \multirow[t]{2}{*}{ Week of May 13} & $0.460^{* * *}$ & $0.347^{* * *}$ & $0.350^{* * *}$ \\
\hline & $(0.077)$ & $(0.070)$ & $(0.067)$ \\
\hline$N$ & 24,884 & 23,336 & 23,336 \\
\hline
\end{tabular}

Table D3: Trends in awareness in first three months of pandemic by firm size

\begin{tabular}{lcc}
\hline & $0-4.5 \mathrm{FTE}$ & $5+\mathrm{FTE}$ \\
\hline Week of March 29 & $0.159^{*}$ & $0.612^{* * *}$ \\
& $(0.094)$ & $(0.112)$ \\
Week of April 1 & $0.165^{*}$ & $0.643^{* * *}$ \\
& $(0.093)$ & $(0.110)$ \\
Week of April 8 & $0.207^{* *}$ & $0.668^{* * *}$ \\
& $(0.093)$ & $(0.111)$ \\
Week of April 15 & $0.222^{* *}$ & $0.702^{* * *}$ \\
& $(0.093)$ & $(0.111)$ \\
Week of May 6 & $0.265^{* * *}$ & $0.709^{* * *}$ \\
& $(0.093)$ & $(0.111)$ \\
Week of May 13 & $0.250^{* * *}$ & $0.718^{* * *}$ \\
& $(0.093)$ & $(0.110)$ \\
$N$ & 15,065 & 9,897
\end{tabular}

Notes: ${ }^{* * *} p<0.01,{ }^{* *} p<0.05,{ }^{*} p<0.1$ Note: Table shows results from baseline survey between March 29 th and May 19th. The weeks of May 20th and May 27th are omitted. All regressions control for a third order polynomial in the number of full-time equivalent employees in January, country dummies, years of education dummies, gender, age group dummies, firm sector, and firm age. Decreasing sample size is a result of within-survey attrition. Estimates are based on the response to the question "Are you aware of any federal or state programs that could help your business during this crisis?" and thus may capture a combination of awareness of the program as well as comprehension of how the program works, who is eligible, and how to apply.

\section{E Appendix: Principal Component Analysis}

This section provides details on our use of Principal Component Analysis (PCA) for dimension reduction of results. We use reduce ten individual outcomes from the baseline sample to three indexes: expectations, outcomes, and approval. The "expectation index" is composed of questions about recovery, future layoffs, and future closure or bankruptcy $(\alpha=0.54)$; the "outcome index" is composed of questions about revenue loss, past layoffs, and permanent closure $(\alpha=$ $0.013)$; and the "approval index" is composed of questions about approval of policies for SMEs, 
workers, and the government's overall response $(\alpha=0.71)$. The $\alpha$ is low for the outcomes index, but quite high for the expectations and approval index. Given the low $\alpha$ for the outcomes index, we show results for key analyses broken out by individual input in Appendix Section F.

Table E1 shows the rotation of each variable at baseline. We impute missing values at baseline and then project the July and November samples onto the baseline PCA. Figure E1 shows a scree plot of proportion of explained variance for each index. The expectations and approval index have large falls in the additional explained variance when including a second component. In addition, for all three PCA models, the first eigenvalue is greater than one, while other eigenvalues are less than one.

Table E2 shows the indexes created by averaging z-scores of the individual outcomes rather than by PCA. As expected, we find similar though smaller coefficients on the association between receiving aid and expectations, outcomes, and approval. In addition, we see the same trends emerge: receiving aid was associated with the largest improvements in expectations in the shortterm; improvements in outcomes and expectations were driven by firms with more than five employees; and the association between receiving aid and improved outcomes and expectations was weakest in November.

Table E1: Rotation of baseline variables for PCA

\begin{tabular}{lccc}
\hline & Expectation & Outcome & Approval \\
\hline Recover two years & -0.538 & & \\
Recover ever & -0.486 & & \\
Expect future layoffs & 0.423 & & \\
Prob. bankruptcy & 0.544 & & \\
Perc. revenue loss & & 0.579 & \\
Past layoffs & & 0.609 & \\
Permanently closed & 0.542 & \\
Approve of SME programs & & & -0.633 \\
Approve of programs for workers & & -0.644 \\
Gov. response was appropriate & & -0.430 \\
\hline
\end{tabular}

Note: Table shows the rotation of baseline variables within each index.

Table E2: Indexes uses averages standardized outcomes

\begin{tabular}{|c|c|c|c|c|c|c|c|c|c|}
\hline & \multicolumn{3}{|c|}{ All } & \multicolumn{3}{|c|}{ 0-4.5 FTE } & \multicolumn{3}{|c|}{$5+$ FTE } \\
\hline & April & July & Nov & April & July & Nov & April & July & Nov \\
\hline Expectation index (avg) & $\begin{array}{c}0.186^{* * *} \\
(0.062)\end{array}$ & $\begin{array}{c}0.184^{* * *} \\
(0.044)\end{array}$ & $\begin{array}{l}0.122^{* *} \\
(0.049)\end{array}$ & $\begin{array}{l}0.184^{*} \\
(0.095)\end{array}$ & $\begin{array}{l}0.127^{* *} \\
(0.064)\end{array}$ & $\begin{array}{c}0.056 \\
(0.074)\end{array}$ & $\begin{array}{l}0.190^{* *} \\
(0.084)\end{array}$ & $\begin{array}{c}0.256^{* * *} \\
(0.063)\end{array}$ & $\begin{array}{l}0.149^{* *} \\
(0.067)\end{array}$ \\
\hline Outcome index (avg) & $\begin{array}{c}0.065 \\
(0.047)\end{array}$ & $\begin{array}{c}0.169^{* * *} \\
(0.033)\end{array}$ & $\begin{array}{l}0.114^{* *} \\
(0.046)\end{array}$ & $\begin{array}{l}0.117^{*} \\
(0.067)\end{array}$ & $\begin{array}{l}0.081^{*} \\
(0.047)\end{array}$ & $\begin{array}{c}0.005 \\
(0.071)\end{array}$ & $\begin{array}{c}0.024 \\
(0.061)\end{array}$ & $\begin{array}{c}0.245^{* * *} \\
(0.045)\end{array}$ & $\begin{array}{l}0.149^{* *} \\
(0.062)\end{array}$ \\
\hline Approval index (avg) & $\begin{array}{c}0.393^{* * *} \\
(0.090) \\
\end{array}$ & $\begin{array}{c}0.205^{* * *} \\
(0.052) \\
\end{array}$ & $\begin{array}{c}0.336^{* * *} \\
(0.061) \\
\end{array}$ & $\begin{array}{c}0.569^{* * *} \\
(0.132) \\
\end{array}$ & $\begin{array}{c}0.056 \\
(0.069) \\
\end{array}$ & $\begin{array}{l}0.167^{*} \\
(0.088) \\
\end{array}$ & $\begin{array}{l}0.255^{* *} \\
(0.118) \\
\end{array}$ & $\begin{array}{c}0.313^{* * *} \\
(0.076) \\
\end{array}$ & $\begin{array}{c}0.431^{* * *} \\
(0.083) \\
\end{array}$ \\
\hline Tumber of respondent & 3,184 & 1,987 & 1,470 & 1,825 & 1,188 & 869 & 1,359 & 799 & 601 \\
\hline
\end{tabular}

Notes: ${ }^{* * *} p<0.01,{ }^{* *} p<0.05,{ }^{*} p<0.1$ The first three columns show results for the full sample, while the remaining columns show results conditional on firm size bins. All regressions control for a third order polynomial in the number of FTE employees in January, awareness of programs at baseline, years of education dummies, gender, age group dummies, firm sector, firm age, country dummies, and the date the survey was completed. The "Expectation index" is composed of questions about recovery, future layoffs, and future closure or bankruptcy; the "Outcome index" is composed of questions about revenue loss, past layoffs, and permanent closure; and the "Approval index" is composed of questions about approval of policies for SMEs, workers, and the government's overall response. 
Figure E1: Scree plot of proportion of explained variance

(a) Expectations index

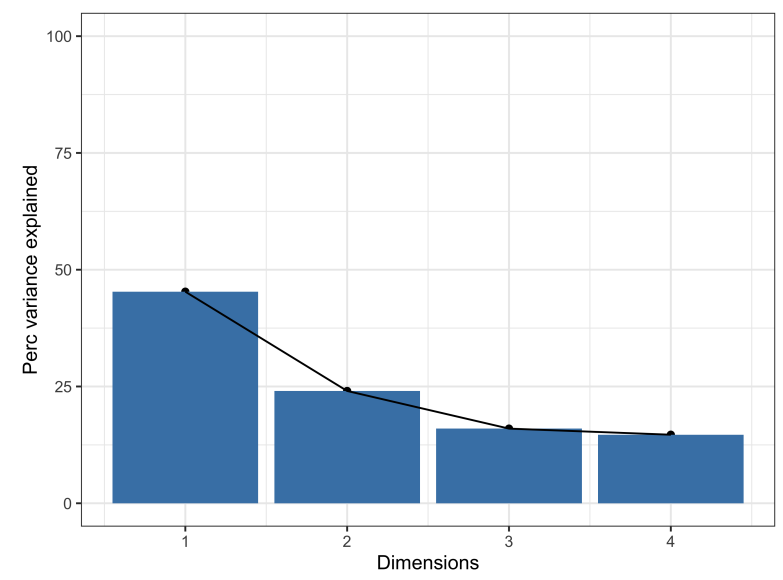

(b) Outcomes index

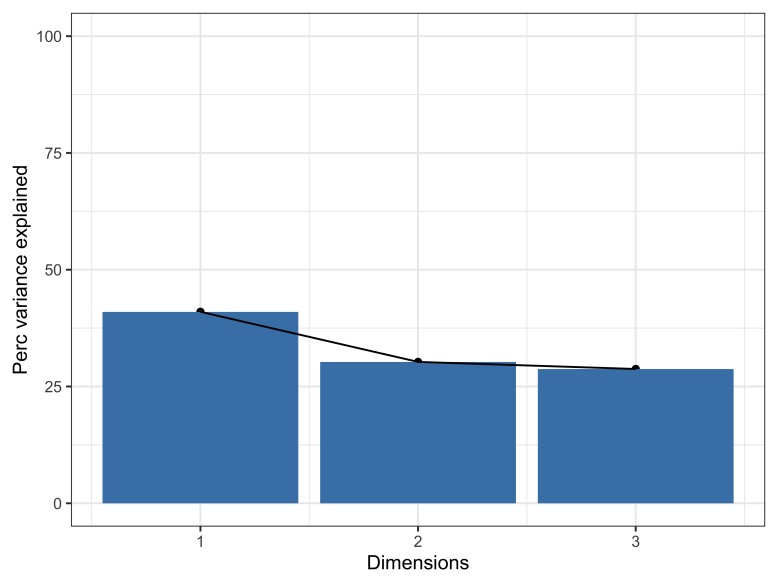

(c) Approval index

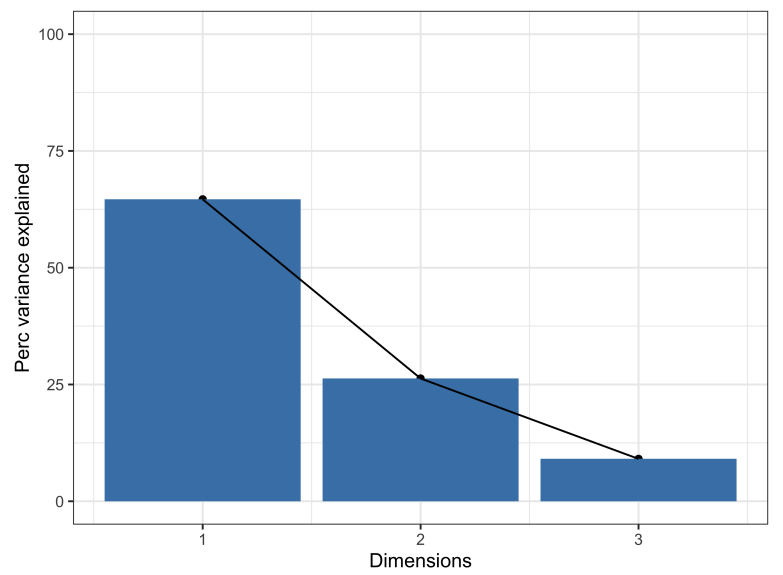

Note: Table shows proportion of explained variance for each of the indexes based on baseline values. For all three PCA models, the first eigenvalue is greater than one, while other eigenvalues are less than one.

\section{F Appendix: Additional results related to access to aid}

This section provides additional results to supplement the analysis of access to aid. Tables F2, F1, F3, F4, and F5 supplement Table 1 from the paper. The first repeats the analysis in the main paper with additional controls for the number of cases and deaths per million people in the country at the time of the study, as well as government stringency. The second repeats the analysis, but with four size bins for firms, separating firms with no employees in January from the 0 to 4.5 group. The third restricts the sample to respondents who completed at least one of the follow-up surveys. The fourth controls for the full expectations index instead of just the recover in two years variable. The fifth excludes Brazil from analysis given that we used a different definition of informality given differing institutional contexts. In Brazil, we asked if firms were registered with the tax authority, while in the seven Spanish-speaking countries we ask if firms are "Formal, making social security contributions." All of the main conclusions hold.

Tables F6, F7, and F3 show the individual outcomes associated with each index in Table 3, as well as provide robustness. Table F7 extends Table 3 by controlling for the number of cases and deaths per million people in the country at the time of the study, as well as government 
stringency. Table F3 restricts the analysis to the sub-sample who completed the original baseline survey and then completed either of the the follow-up surveys.

Table F1: Access to aid and firm characteristics (four employment groups)

\begin{tabular}{|c|c|c|c|c|c|c|c|c|c|}
\hline & \multicolumn{3}{|c|}{ Aware of programs } & \multicolumn{3}{|c|}{ Applied } & \multicolumn{3}{|c|}{ Received help } \\
\hline & April & July & Nov & April & July & Nov & April & July & Nov \\
\hline $0 \mathrm{FTE}$ & $\begin{array}{c}-0.079^{* *} \\
(0.033)\end{array}$ & $\begin{array}{l}-0.029 \\
(0.068)\end{array}$ & $\begin{array}{c}-0.270^{* * *} \\
(0.088)\end{array}$ & $\begin{array}{c}-0.099^{* * *} \\
(0.025)\end{array}$ & $\begin{array}{c}-0.136^{* *} \\
(0.060)\end{array}$ & $\begin{array}{c}-0.220^{* *} \\
(0.091)\end{array}$ & $\begin{array}{l}-0.013 \\
(0.026)\end{array}$ & $\begin{array}{c}-0.159^{* * *} \\
(0.046)\end{array}$ & $\begin{array}{c}-0.182^{* *} \\
(0.073)\end{array}$ \\
\hline 0.5-4.5 FTE & $\begin{array}{c}-0.086^{* * *} \\
(0.015)\end{array}$ & $\begin{array}{c}-0.064^{*} \\
(0.034)\end{array}$ & $\begin{array}{c}-0.153^{* * *} \\
(0.036)\end{array}$ & $\begin{array}{c}-0.074^{* * *} \\
(0.013)\end{array}$ & $\begin{array}{c}-0.089^{* * *} \\
(0.030)\end{array}$ & $\begin{array}{c}-0.163^{* * *} \\
(0.037)\end{array}$ & $\begin{array}{c}-0.028^{* *} \\
(0.012)\end{array}$ & $\begin{array}{c}-0.122^{* * *} \\
(0.026)\end{array}$ & $\begin{array}{c}-0.213^{* * * *} \\
(0.033)\end{array}$ \\
\hline 5-9.5 FTE & $\begin{array}{c}-0.032^{*} \\
(0.017)\end{array}$ & $\begin{array}{l}-0.005 \\
(0.036)\end{array}$ & $\begin{array}{c}-0.126^{* * *} \\
(0.040)\end{array}$ & $\begin{array}{c}-0.034^{* *} \\
(0.014)\end{array}$ & $\begin{array}{l}-0.049 \\
(0.034)\end{array}$ & $\begin{array}{c}-0.105^{\text {*** }} \\
(0.041)\end{array}$ & $\begin{array}{c}-0.031^{\text {*** }} \\
(0.013)\end{array}$ & $\begin{array}{c}-0.095^{* * *} \\
(0.030)\end{array}$ & $\begin{array}{c}-0.132^{\text {*** }} \\
(0.037)\end{array}$ \\
\hline Years of schooling & $\begin{array}{c}0.020^{* * *} \\
(0.003)\end{array}$ & $\begin{array}{c}0.015^{* * * *} \\
(0.006)\end{array}$ & $\begin{array}{l}-0.005 \\
(0.007)\end{array}$ & $\begin{array}{c}0.005^{* * *} \\
(0.002)\end{array}$ & $\begin{array}{c}0.003 \\
(0.006)\end{array}$ & $\begin{array}{c}0.004 \\
(0.007)\end{array}$ & $\begin{array}{c}0.007^{\text {*k* }} \\
(0.002)\end{array}$ & $\begin{array}{l}0.009^{*} \\
(0.005)\end{array}$ & $\begin{array}{c}0.009 \\
(0.006)\end{array}$ \\
\hline Aware of programs (April) & & $\begin{array}{c}0.333^{* * *} \\
(0.027)\end{array}$ & $\begin{array}{c}0.241^{* * *} \\
(0.030)\end{array}$ & $\begin{array}{c}0.185^{* * *} \\
(0.009)\end{array}$ & $\begin{array}{c}0.177^{* * *} \\
(0.024)\end{array}$ & $\begin{array}{c}0.200^{* * *} \\
(0.030)\end{array}$ & $\begin{array}{c}0.076^{* * * *} \\
(0.008)\end{array}$ & $\begin{array}{c}0.131^{* * *} \\
(0.020)\end{array}$ & $\begin{array}{c}0.151^{* * * *} \\
(0.025)\end{array}$ \\
\hline Recover in two years (April) & $\begin{array}{c}0.060^{\text {**** }} \\
(0.011)\end{array}$ & $\begin{array}{c}0.043^{*} \\
(0.026)\end{array}$ & $\begin{array}{c}0.027 \\
(0.030)\end{array}$ & $\begin{array}{l}-0.008 \\
(0.009)\end{array}$ & $\begin{array}{l}-0.016 \\
(0.023)\end{array}$ & $\begin{array}{c}0.034 \\
(0.028)\end{array}$ & $\begin{array}{c}0.007 \\
(0.008)\end{array}$ & $\begin{array}{c}0.021 \\
(0.018)\end{array}$ & $\begin{array}{c}0.009 \\
(0.023) \\
\end{array}$ \\
\hline
\end{tabular}

Notes: ${ }^{* * *} p<0.01,{ }^{* *} p<0.05,{ }^{*} p<0.1$. All regressions control for day of week, country dummies, and the date the survey was completed. All regressions also include controls for industry, age dummies, firm age, and gender, but coefficients were largely not statistically significant nor large and are not displayed as they largely did not predict the outcomes. The omitted category for firm-size bins is firms with 10-150 FTE employees.

Table F2: Access to aid and firm characteristics (additional controls)

\begin{tabular}{|c|c|c|c|c|c|c|c|c|c|}
\hline & \multicolumn{3}{|c|}{ Aware of programs } & \multicolumn{3}{|c|}{ Applied } & \multicolumn{3}{|c|}{ Received help } \\
\hline & April & July & Nov & April & July & Nov & April & July & Nov \\
\hline $0-4.5 \mathrm{FTE}$ & $\begin{array}{c}-0.064^{* * *} \\
(0.011)\end{array}$ & $\begin{array}{c}-0.059^{* *} \\
(0.025)\end{array}$ & $\begin{array}{c}-0.083^{* * *} \\
(0.028)\end{array}$ & $\begin{array}{c}-0.054^{* * *} \\
(0.009)\end{array}$ & $\begin{array}{c}-0.063^{* * *} \\
(0.023)\end{array}$ & $\begin{array}{c}-0.103^{* * *} \\
(0.027)\end{array}$ & $\begin{array}{l}-0.009 \\
(0.008)\end{array}$ & $\begin{array}{c}-0.069^{* * *} \\
(0.018)\end{array}$ & $\begin{array}{c}-0.135^{\text {*** }} \\
(0.023)\end{array}$ \\
\hline Informal & $\begin{array}{c}-0.085^{* * *} \\
(0.014)\end{array}$ & $\begin{array}{c}-0.071^{* *} \\
(0.031)\end{array}$ & $\begin{array}{c}-0.156^{* * *} \\
(0.033)\end{array}$ & $\begin{array}{c}-0.036^{* * *} \\
(0.009)\end{array}$ & $\begin{array}{c}-0.157^{* * *} \\
(0.029)\end{array}$ & $\begin{array}{c}-0.137^{* * *} \\
(0.030)\end{array}$ & $\begin{array}{l}-0.007 \\
(0.008)\end{array}$ & $\begin{array}{c}-0.098^{* * *} \\
(0.019)\end{array}$ & $\begin{array}{c}-0.085^{* * *} \\
(0.021)\end{array}$ \\
\hline Years of schooling & $\begin{array}{c}0.020^{* * *} \\
(0.003)\end{array}$ & $\begin{array}{c}0.016^{* * *} \\
(0.006)\end{array}$ & $\begin{array}{l}-0.002 \\
(0.007)\end{array}$ & $\begin{array}{c}0.006^{* * *} \\
(0.002)\end{array}$ & $\begin{array}{c}0.003 \\
(0.006)\end{array}$ & $\begin{array}{c}0.006 \\
(0.007)\end{array}$ & $\begin{array}{c}0.008^{* * *} \\
(0.002)\end{array}$ & $\begin{array}{l}0.010^{* * *} \\
(0.005)\end{array}$ & $\begin{array}{c}0.010^{*} \\
(0.006)\end{array}$ \\
\hline Recover in two years (April) & $\begin{array}{c}0.061^{* * *} \\
(0.011)\end{array}$ & $\begin{array}{l}0.044^{*} \\
(0.026)\end{array}$ & $\begin{array}{c}0.024 \\
(0.030)\end{array}$ & $\begin{array}{c}-0.008 \\
(0.009)\end{array}$ & $\begin{array}{l}-0.018 \\
(0.023)\end{array}$ & $\begin{array}{c}0.031 \\
(0.028)\end{array}$ & $\begin{array}{c}0.007 \\
(0.008)\end{array}$ & $\begin{array}{c}0.017 \\
(0.018)\end{array}$ & $\begin{array}{c}0.006 \\
(0.023)\end{array}$ \\
\hline Mean & 0.349 & 0.459 & 0.474 & 0.156 & 0.433 & 0.395 & 0.045 & 0.17 & 0.199 \\
\hline$N$ & 8,426 & 1,488 & 1,310 & 7,643 & 1,984 & 1,311 & 3,184 & 1,821 & 1,307 \\
\hline
\end{tabular}

Notes: ${ }^{* * *} p<0.01,{ }^{* *} p<0.05,{ }^{*} p<0.1$. All regressions control for day of week, country dummies, the date the survey was completed, total COVID-19 cases per million people by country, total COVID-19 deaths per million people by country, and government stringency by country. All regressions also include controls for industry, age dummies, firm age, and gender, but coefficients were largely not statistically significant nor large and are not displayed as they largely did not predict the outcomes. The omitted category for firm-size bins is firms with 5-150 FTE employees. 
Table F3: Access to aid and firm characteristics (balanced panel)

\begin{tabular}{|c|c|c|c|c|c|c|c|c|c|}
\hline & \multicolumn{3}{|c|}{ Aware of programs } & \multicolumn{3}{|c|}{ Applied } & \multicolumn{3}{|c|}{ Received help } \\
\hline & April & July & Nov & April & July & Nov & April & July & Nov \\
\hline $0-4.5 \mathrm{FTE}$ & $\begin{array}{c}-0.070^{* * *} \\
(0.027)\end{array}$ & $\begin{array}{c}-0.059^{* *} \\
(0.025)\end{array}$ & $\begin{array}{c}-0.083^{* * *} \\
(0.028)\end{array}$ & $\begin{array}{c}-0.070^{* * * *} \\
(0.021)\end{array}$ & $\begin{array}{c}-0.064^{* * *} \\
(0.023)\end{array}$ & $\begin{array}{c}-0.104^{* * *} \\
(0.027)\end{array}$ & $\begin{array}{l}-0.014 \\
(0.016)\end{array}$ & $\begin{array}{c}-0.070^{* * *} \\
(0.018)\end{array}$ & $\begin{array}{c}-0.135^{\text {*** }} \\
(0.023)\end{array}$ \\
\hline Informal & $\begin{array}{c}-0.074^{* *} \\
(0.031)\end{array}$ & $\begin{array}{c}-0.071^{* *} \\
(0.031)\end{array}$ & $\begin{array}{c}-0.160^{* * *} \\
(0.033)\end{array}$ & $\begin{array}{c}-0.050^{* *} \\
(0.019)\end{array}$ & $\begin{array}{c}-0.154^{* * * *} \\
(0.029)\end{array}$ & $\begin{array}{c}-0.137^{* * * *} \\
(0.030)\end{array}$ & $\begin{array}{l}-0.011 \\
(0.017)\end{array}$ & $\begin{array}{c}-0.098^{* * *} \\
(0.019)\end{array}$ & $\begin{array}{c}-0.085^{* * * *} \\
(0.021)\end{array}$ \\
\hline Years of schooling & $\begin{array}{c}0.033^{* * *} \\
(0.006)\end{array}$ & $\begin{array}{c}0.016^{* * *} \\
(0.006)\end{array}$ & $\begin{array}{l}-0.003 \\
(0.007)\end{array}$ & $\begin{array}{l}0.008^{*} \\
(0.005)\end{array}$ & $\begin{array}{c}0.003 \\
(0.006)\end{array}$ & $\begin{array}{c}0.005 \\
(0.007)\end{array}$ & $\begin{array}{c}0.013^{* * *} \\
(0.004)\end{array}$ & $\begin{array}{l}0.009^{* *} \\
(0.005)\end{array}$ & $\begin{array}{l}0.010^{*} \\
(0.006)\end{array}$ \\
\hline Aware of programs (May) & & $\begin{array}{c}0.333^{* * *} \\
(0.026)\end{array}$ & $\begin{array}{c}0.243^{* * * *} \\
(0.030)\end{array}$ & $\begin{array}{c}0.197^{* * *} \\
(0.022)\end{array}$ & $\begin{array}{c}0.179^{* * * *} \\
(0.024)\end{array}$ & $\begin{array}{c}0.201^{* * * *} \\
(0.030)\end{array}$ & $\begin{array}{c}0.076^{* * *} \\
(0.017)\end{array}$ & $\begin{array}{c}0.133^{* * *} \\
(0.020)\end{array}$ & $\begin{array}{c}0.151^{* * * *} \\
(0.026)\end{array}$ \\
\hline Recover in two years (May) & $\begin{array}{c}0.042 \\
(0.028)\end{array}$ & $\begin{array}{c}0.044^{*} \\
(0.026)\end{array}$ & $\begin{array}{c}0.022 \\
(0.030)\end{array}$ & $\begin{array}{l}-0.028 \\
(0.021)\end{array}$ & $\begin{array}{l}-0.018 \\
(0.023)\end{array}$ & $\begin{array}{c}0.031 \\
(0.028)\end{array}$ & $\begin{array}{c}0.006 \\
(0.017)\end{array}$ & $\begin{array}{c}0.017 \\
(0.018)\end{array}$ & $\begin{array}{c}0.006 \\
(0.023)\end{array}$ \\
\hline Mean & 0.342 & 0.459 & 0.474 & 0.18 & 0.433 & 0.395 & 0.063 & 0.17 & 0.199 \\
\hline$N$ & 1,451 & 1,488 & 1,310 & 1,419 & 1,984 & 1,311 & 939 & 1,821 & 1,307 \\
\hline
\end{tabular}

Table F4: Access to aid and firm characteristics (controlling for full expectations index)

\begin{tabular}{|c|c|c|c|c|c|c|c|c|c|}
\hline & \multicolumn{3}{|c|}{ Aware of programs } & \multicolumn{3}{|c|}{ Applied } & \multicolumn{3}{|c|}{ Received help } \\
\hline & April & July & Nov & April & July & Nov & April & July & Nov \\
\hline $0-4.5 \mathrm{FTE}$ & $\begin{array}{c}-0.063^{* * *} \\
(0.010)\end{array}$ & $\begin{array}{c}-0.065^{* *} \\
(0.032)\end{array}$ & $\begin{array}{c}-0.093^{* *} \\
(0.038)\end{array}$ & $\begin{array}{c}-0.046^{* * *} \\
(0.008)\end{array}$ & $\begin{array}{c}-0.056^{*} \\
(0.032)\end{array}$ & $\begin{array}{c}-0.133^{* * *} \\
(0.039)\end{array}$ & $\begin{array}{c}-0.010 \\
(0.008)\end{array}$ & $\begin{array}{l}-0.039 \\
(0.025)\end{array}$ & $\begin{array}{c}-0.094^{* * *} \\
(0.030)\end{array}$ \\
\hline Informal & $\begin{array}{c}-0.071^{* * *} \\
(0.013)\end{array}$ & $\begin{array}{l}-0.054 \\
(0.038)\end{array}$ & $\begin{array}{c}-0.137^{* * *} \\
(0.044)\end{array}$ & $\begin{array}{c}-0.028^{* * *} \\
(0.008)\end{array}$ & $\begin{array}{c}-0.173^{* * *} \\
(0.036)\end{array}$ & $\begin{array}{c}-0.127^{* * *} \\
(0.040)\end{array}$ & $\begin{array}{l}-0.006 \\
(0.008)\end{array}$ & $\begin{array}{c}-0.116^{* * *} \\
(0.025)\end{array}$ & $\begin{array}{c}-0.081^{* * *} \\
(0.027)\end{array}$ \\
\hline Years of schooling & $\begin{array}{c}0.017^{* * *} \\
(0.003)\end{array}$ & $\begin{array}{c}0.010 \\
(0.007)\end{array}$ & $\begin{array}{l}-0.003 \\
(0.009)\end{array}$ & $\begin{array}{c}0.006^{* * *} \\
(0.002)\end{array}$ & $\begin{array}{c}0.003 \\
(0.007)\end{array}$ & $\begin{array}{c}0.006 \\
(0.009)\end{array}$ & $\begin{array}{c}0.007^{* * *} \\
(0.002)\end{array}$ & $\begin{array}{l}0.012^{\text {** }} \\
(0.006)\end{array}$ & $\begin{array}{c}0.013^{*} \\
(0.007)\end{array}$ \\
\hline Aware of programs (April) & & $\begin{array}{c}0.360^{* * * *} \\
(0.032)\end{array}$ & $\begin{array}{c}0.238^{* * *} \\
(0.039)\end{array}$ & $\begin{array}{c}0.225^{* * *} \\
(0.009)\end{array}$ & $\begin{array}{c}0.195^{* * *} \\
(0.031)\end{array}$ & $\begin{array}{c}0.206^{* * * *} \\
(0.039)\end{array}$ & $\begin{array}{c}0.076^{* * *} \\
(0.008)\end{array}$ & $\begin{array}{c}0.140^{* * *} \\
(0.026)\end{array}$ & $\begin{array}{c}0.152^{\text {*** }} \\
(0.031)\end{array}$ \\
\hline Expectation index (April) & $\begin{array}{c}0.034^{\text {*** }} \\
(0.005)\end{array}$ & $\begin{array}{c}0.013 \\
(0.014)\end{array}$ & $\begin{array}{c}0.029^{*} \\
(0.016)\end{array}$ & $\begin{array}{c}-0.011^{* * *} \\
(0.004)\end{array}$ & $\begin{array}{c}-0.027^{* *} \\
(0.014)\end{array}$ & $\begin{array}{c}0.007 \\
(0.016) \\
\end{array}$ & $\begin{array}{l}0.008^{* *} \\
(0.004)\end{array}$ & $\begin{array}{l}0.028^{* *} \\
(0.011)\end{array}$ & $\begin{array}{l}0.025^{*} \\
(0.013)\end{array}$ \\
\hline Mean & 0.349 & 0.459 & 0.474 & 0.156 & 0.433 & 0.395 & 0.045 & 0.17 & 0.199 \\
\hline$N$ & 9,546 & 982 & 743 & 8,514 & 1,093 & 744 & 3,184 & 974 & 743 \\
\hline
\end{tabular}

Notes: ${ }^{* * *} p<0.01,{ }^{* *} p<0.05,{ }^{*} p<0.1$. All regressions control for day of week, country dummies, and the date the survey was completed. All regressions also include controls for industry, age dummies, firm age, and gender, but coefficients were largely not statistically significant nor large and are not displayed as they largely did not predict the outcomes. The omitted category for firm size bins is firms with 5-150 FTE employees. The change in sample size upon controlling for the expectations index is because we only use observations after April 19, 2020 to create the indexes. 
Table F5: Access to aid and firm characteristics (excluding Brazil)

\begin{tabular}{|c|c|c|c|c|c|c|c|c|c|}
\hline & \multicolumn{3}{|c|}{ Aware of programs } & \multicolumn{3}{|c|}{ Applied } & \multicolumn{3}{|c|}{ Received help } \\
\hline & April & July & Nov & April & July & Nov & April & July & Nov \\
\hline $0-4.5 \mathrm{FTE}$ & $\begin{array}{c}-0.064^{* * *} \\
(0.011)\end{array}$ & $\begin{array}{c}-0.054^{* *} \\
(0.026)\end{array}$ & $\begin{array}{c}-0.087^{* * *} \\
(0.029)\end{array}$ & $\begin{array}{c}-0.049^{* * *} \\
(0.009)\end{array}$ & $\begin{array}{c}-0.063^{* * *} \\
(0.023)\end{array}$ & $\begin{array}{c}-0.103^{* * *} \\
(0.028)\end{array}$ & $\begin{array}{l}-0.009 \\
(0.008)\end{array}$ & $\begin{array}{c}-0.067^{* * *} \\
(0.018)\end{array}$ & $\begin{array}{c}-0.136^{* * *} \\
(0.023)\end{array}$ \\
\hline Informal & $\begin{array}{c}-0.089^{* * *} \\
(0.014)\end{array}$ & $\begin{array}{c}-0.074^{* *} \\
(0.031)\end{array}$ & $\begin{array}{c}-0.161^{* * * *} \\
(0.033)\end{array}$ & $\begin{array}{c}-0.039^{* * *} \\
(0.009)\end{array}$ & $\begin{array}{c}-0.158^{* * *} \\
(0.029)\end{array}$ & $\begin{array}{c}-0.138^{* * *} \\
(0.030)\end{array}$ & $\begin{array}{l}-0.009 \\
(0.008)\end{array}$ & $\begin{array}{c}-0.099^{* * *} \\
(0.019)\end{array}$ & $\begin{array}{c}-0.085^{* * * *} \\
(0.021)\end{array}$ \\
\hline Years of schooling & $\begin{array}{c}0.017^{* * *} \\
(0.003)\end{array}$ & $\begin{array}{c}0.017^{* * * *} \\
(0.006)\end{array}$ & $\begin{array}{l}-0.004 \\
(0.007)\end{array}$ & $\begin{array}{c}0.006^{* * * *} \\
(0.002)\end{array}$ & $\begin{array}{c}0.001 \\
(0.006)\end{array}$ & $\begin{array}{c}0.004 \\
(0.007)\end{array}$ & $\begin{array}{c}0.007^{* * * *} \\
(0.002)\end{array}$ & $\begin{array}{l}0.010^{*} \\
(0.005)\end{array}$ & $\begin{array}{l}0.010^{*} \\
(0.006)\end{array}$ \\
\hline Aware of programs (April) & & $\begin{array}{c}0.331^{* * *} \\
(0.028)\end{array}$ & $\begin{array}{c}0.233^{\text {*** }} \\
(0.030)\end{array}$ & $\begin{array}{c}0.201^{* * *} \\
(0.010)\end{array}$ & $\begin{array}{c}0.176^{* * *} \\
(0.025)\end{array}$ & $\begin{array}{c}0.194^{* * *} \\
(0.030)\end{array}$ & $\begin{array}{c}0.074^{* * *} \\
(0.009)\end{array}$ & $\begin{array}{c}0.135^{\text {*** }} \\
(0.021)\end{array}$ & $\begin{array}{c}0.150^{* * *} \\
(0.026)\end{array}$ \\
\hline Recover in two years (April) & $\begin{array}{c}0.062^{\text {*** }} \\
(0.012)\end{array}$ & $\begin{array}{c}0.046^{*} \\
(0.027)\end{array}$ & $\begin{array}{c}0.020 \\
(0.030)\end{array}$ & $\begin{array}{c}-0.002 \\
(0.009)\end{array}$ & $\begin{array}{c}-0.018 \\
(0.024)\end{array}$ & $\begin{array}{c}0.030 \\
(0.028)\end{array}$ & $\begin{array}{c}0.001 \\
(0.008)\end{array}$ & $\begin{array}{c}0.011 \\
(0.019)\end{array}$ & $\begin{array}{c}0.004 \\
(0.024)\end{array}$ \\
\hline Mean & 0.341 & 0.438 & 0.463 & 0.15 & 0.432 & 0.378 & 0.044 & 0.164 & 0.19 \\
\hline$N$ & 7,653 & 1,403 & 1,285 & 6,919 & 1,907 & 1,286 & 2,962 & 1,748 & 1,282 \\
\hline
\end{tabular}

Table F6: Access to aid and expectations, outcomes, and approval of government policies (full results)

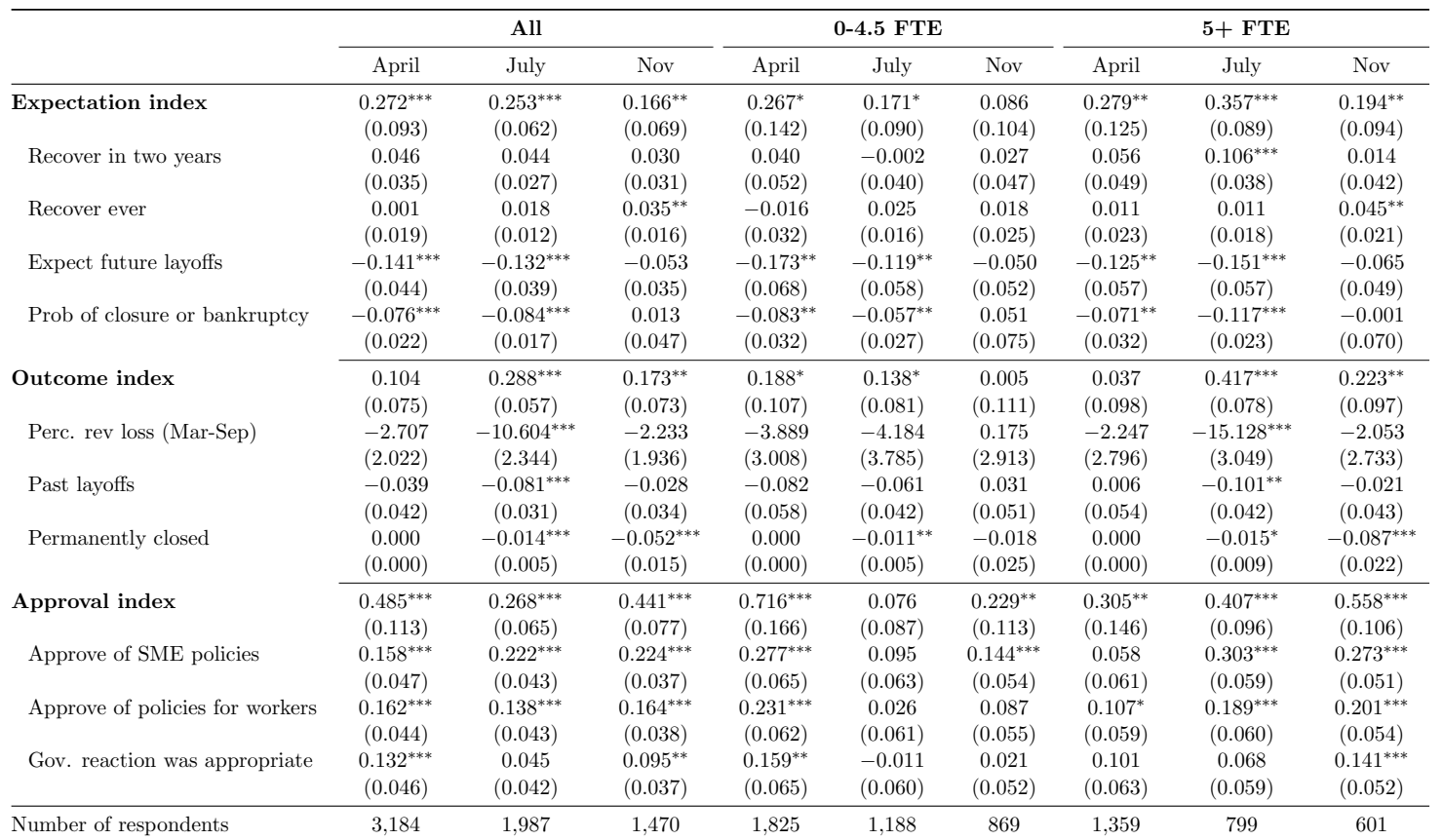

Notes: ${ }^{* * *} p<0.01,{ }^{* *} p<0.05,{ }^{*} p<0.1$ The first three columns show results for the full sample, while the remaining columns show results conditional on firm size bins. All regressions control for a third order polynomial in the number of FTE employees in January, awareness of programs at baseline, years of education dummies, gender, age group dummies, firm sector, firm age, country dummies, and the date the survey was completed. Missing values have been imputed based on data after April 19, 2020, when we began asking firm owners if they had received aid. 
Table F7: Access to aid and expectations, outcomes, and approval of government policies (full results with additional controls)

\begin{tabular}{|c|c|c|c|c|c|c|c|c|c|}
\hline & \multicolumn{3}{|c|}{ All } & \multicolumn{3}{|c|}{ 0-4.5 FTE } & \multicolumn{3}{|c|}{$5+$ FTE } \\
\hline & April & July & Nov & April & July & Nov & April & July & Nov \\
\hline Expectation index & $\begin{array}{c}0.274^{* * *} \\
(0.092)\end{array}$ & $\begin{array}{c}0.251^{* * * *} \\
(0.062)\end{array}$ & $\begin{array}{l}0.166^{* *} \\
(0.070)\end{array}$ & $\begin{array}{l}0.267^{*} \\
(0.141)\end{array}$ & $\begin{array}{l}0.171^{*} \\
(0.090)\end{array}$ & $\begin{array}{c}0.086 \\
(0.105)\end{array}$ & $\begin{array}{l}0.283^{* *} \\
(0.123)\end{array}$ & $\begin{array}{c}0.349^{* * * *} \\
(0.089)\end{array}$ & $\begin{array}{l}0.201^{* *} \\
(0.094)\end{array}$ \\
\hline Recover in two years & $\begin{array}{c}0.048 \\
(0.036)\end{array}$ & $\begin{array}{c}0.043 \\
(0.027)\end{array}$ & $\begin{array}{c}0.029 \\
(0.031)\end{array}$ & $\begin{array}{c}0.040 \\
(0.052)\end{array}$ & $\begin{array}{c}-0.002 \\
(0.040)\end{array}$ & $\begin{array}{c}0.030 \\
(0.047)\end{array}$ & $\begin{array}{c}0.058 \\
(0.049)\end{array}$ & $\begin{array}{c}0.103^{* * *} \\
(0.038)\end{array}$ & $\begin{array}{c}0.018 \\
(0.042)\end{array}$ \\
\hline Recover ever & $\begin{array}{c}0.001 \\
(0.019)\end{array}$ & $\begin{array}{c}0.018 \\
(0.012)\end{array}$ & $\begin{array}{l}0.036^{* * *} \\
(0.016)\end{array}$ & $\begin{array}{l}-0.015 \\
(0.031)\end{array}$ & $\begin{array}{c}0.025 \\
(0.015)\end{array}$ & $\begin{array}{c}0.017 \\
(0.025)\end{array}$ & $\begin{array}{c}0.012 \\
(0.022)\end{array}$ & $\begin{array}{c}0.010 \\
(0.018)\end{array}$ & $\begin{array}{l}0.047^{* * *} \\
(0.021)\end{array}$ \\
\hline Expect future layoffs & $\begin{array}{c}-0.141^{* * * *} \\
(0.044)\end{array}$ & $\begin{array}{c}-0.131^{* * *} \\
(0.039)\end{array}$ & $\begin{array}{l}-0.053 \\
(0.035)\end{array}$ & $\begin{array}{c}-0.175^{* *} \\
(0.068)\end{array}$ & $\begin{array}{c}-0.118^{* *} \\
(0.058)\end{array}$ & $\begin{array}{l}-0.050 \\
(0.053)\end{array}$ & $\begin{array}{c}-0.125^{* *} \\
(0.057)\end{array}$ & $\begin{array}{c}-0.148^{* * *} \\
(0.057)\end{array}$ & $\begin{array}{l}-0.067 \\
(0.049)\end{array}$ \\
\hline Prob of closure or bankruptcy & $\begin{array}{c}-0.077^{* * *} \\
(0.022)\end{array}$ & $\begin{array}{c}-0.083^{* * *} \\
(0.017)\end{array}$ & $\begin{array}{c}0.010 \\
(0.049)\end{array}$ & $\begin{array}{c}-0.082^{* *} \\
(0.032)\end{array}$ & $\begin{array}{c}-0.057^{* *} \\
(0.027)\end{array}$ & $\begin{array}{c}0.045 \\
(0.079)\end{array}$ & $\begin{array}{c}-0.072^{* *} \\
(0.031)\end{array}$ & $\begin{array}{c}-0.116^{* * *} \\
(0.023)\end{array}$ & $\begin{array}{l}-0.035 \\
(0.074)\end{array}$ \\
\hline Outcome index & $\begin{array}{c}0.100 \\
(0.076)\end{array}$ & $\begin{array}{c}0.286^{* * *} \\
(0.057)\end{array}$ & $\begin{array}{l}0.172^{* *} \\
(0.073)\end{array}$ & $\begin{array}{l}0.179^{*} \\
(0.109)\end{array}$ & $\begin{array}{l}0.140^{*} \\
(0.081)\end{array}$ & $\begin{array}{l}-0.007 \\
(0.112)\end{array}$ & $\begin{array}{c}0.036 \\
(0.098)\end{array}$ & $\begin{array}{c}0.401^{* * *} \\
(0.077)\end{array}$ & $\begin{array}{l}0.213^{* *} \\
(0.097)\end{array}$ \\
\hline Perc. rev loss (Mar-Sep) & $\begin{array}{l}-2.543 \\
(2.029)\end{array}$ & $\begin{array}{c}-10.592^{* * *} \\
(2.338)\end{array}$ & $\begin{array}{l}-2.271 \\
(1.936)\end{array}$ & $\begin{array}{l}-3.649 \\
(3.046)\end{array}$ & $\begin{array}{l}-4.246 \\
(3.783)\end{array}$ & $\begin{array}{c}0.127 \\
(2.939)\end{array}$ & $\begin{array}{l}-2.141 \\
(2.802)\end{array}$ & $\begin{array}{c}-14.782^{* * *} \\
(3.034)\end{array}$ & $\begin{array}{l}-2.013 \\
(2.732)\end{array}$ \\
\hline Past layoffs & $\begin{array}{l}-0.038 \\
(0.042)\end{array}$ & $\begin{array}{c}-0.081^{* * *} \\
(0.031)\end{array}$ & $\begin{array}{l}-0.027 \\
(0.034)\end{array}$ & $\begin{array}{r}-0.078 \\
(0.057)\end{array}$ & $\begin{array}{r}-0.062 \\
(0.042)\end{array}$ & $\begin{array}{c}0.037 \\
(0.051)\end{array}$ & $\begin{array}{c}0.006 \\
(0.054)\end{array}$ & $\begin{array}{c}-0.096^{* *} \\
(0.042)\end{array}$ & $\begin{array}{l}-0.017 \\
(0.044)\end{array}$ \\
\hline Permanently closed & $\begin{array}{c}0.000 \\
(0.000)\end{array}$ & $\begin{array}{c}-0.013^{* * * *} \\
(0.005)\end{array}$ & $\begin{array}{c}-0.052^{* * *} \\
(0.015)\end{array}$ & $\begin{array}{c}0.000 \\
(0.000)\end{array}$ & $\begin{array}{c}-0.011^{* *} \\
(0.005)\end{array}$ & $\begin{array}{l}-0.016 \\
(0.024)\end{array}$ & $\begin{array}{c}0.000 \\
(0.000)\end{array}$ & $\begin{array}{l}-0.014 \\
(0.009)\end{array}$ & $\begin{array}{c}-0.086^{* * *} \\
(0.022)\end{array}$ \\
\hline Approval index & $\begin{array}{c}0.488^{* * *} \\
(0.114)\end{array}$ & $\begin{array}{c}0.263^{* * *} \\
(0.064)\end{array}$ & $\begin{array}{c}0.441^{* * *} \\
(0.077)\end{array}$ & $\begin{array}{c}0.711^{* * *} \\
(0.166)\end{array}$ & $\begin{array}{c}0.071 \\
(0.086)\end{array}$ & $\begin{array}{l}0.221^{*} \\
(0.113)\end{array}$ & $\begin{array}{l}0.314^{* *} \\
(0.149)\end{array}$ & $\begin{array}{c}0.403^{* * * *} \\
(0.096)\end{array}$ & $\begin{array}{c}0.566^{* * *} \\
(0.105)\end{array}$ \\
\hline Approve of SME policies & $\begin{array}{c}0.160^{* * * *} \\
(0.047)\end{array}$ & $\begin{array}{c}0.220^{* * *} \\
(0.043)\end{array}$ & $\begin{array}{c}0.224^{* * *} \\
(0.037)\end{array}$ & $\begin{array}{c}0.279^{* * * *} \\
(0.065)\end{array}$ & $\begin{array}{c}0.093 \\
(0.064)\end{array}$ & $\begin{array}{l}0.138^{* *} \\
(0.054)\end{array}$ & $\begin{array}{c}0.062 \\
(0.063)\end{array}$ & $\begin{array}{c}0.300^{* * * *} \\
(0.059)\end{array}$ & $\begin{array}{c}0.275^{* * *} \\
(0.051)\end{array}$ \\
\hline Approve of policies for workers & $\begin{array}{c}0.162^{* * * *} \\
(0.045)\end{array}$ & $\begin{array}{c}0.135^{* * * *} \\
(0.043)\end{array}$ & $\begin{array}{c}0.164^{* * *} \\
(0.038)\end{array}$ & $\begin{array}{c}0.225^{* * * *} \\
(0.063)\end{array}$ & $\begin{array}{c}0.023 \\
(0.060)\end{array}$ & $\begin{array}{c}0.083 \\
(0.055)\end{array}$ & $\begin{array}{l}0.114^{*} \\
(0.061)\end{array}$ & $\begin{array}{c}0.186^{* * * *} \\
(0.060)\end{array}$ & $\begin{array}{c}0.204^{* * * *} \\
(0.054)\end{array}$ \\
\hline Gov. reaction was appropriate & $\begin{array}{c}0.134^{* * * *} \\
(0.046)\end{array}$ & $\begin{array}{c}0.042 \\
(0.042) \\
\end{array}$ & $\begin{array}{l}0.094^{* *} \\
(0.037)\end{array}$ & $\begin{array}{l}0.156^{* * *} \\
(0.065)\end{array}$ & $\begin{array}{l}-0.016 \\
(0.060)\end{array}$ & $\begin{array}{c}0.023 \\
(0.052) \\
\end{array}$ & $\begin{array}{c}0.106^{*} \\
(0.063)\end{array}$ & $\begin{array}{c}0.065 \\
(0.059) \\
\end{array}$ & $\begin{array}{c}0.143^{\text {**** }} \\
(0.052)\end{array}$ \\
\hline Number of respondents & 3,184 & 1,987 & 1,470 & 1,825 & 1,188 & 869 & 1,359 & 799 & 601 \\
\hline
\end{tabular}

Notes: ${ }^{* * *} p<0.01,{ }^{* *} p<0.05,{ }^{*} p<0.1$. All regressions control for a third order polynomial in the number of full-time equivalent employees in January, the day of the week the survey was completed, awareness of programs at baseline, years of education dummies, gender, age group dummies, firm sector, firm age, country dummies, and the date the survey was completed. Compared to Table 3, this table additionally controls for total COVID-19 cases per million people by country, total COVID-19 deaths per million people by country, and government stringency by country. Missing values have been imputed based on data after April 19, 2020, when we began asking firm owners if they had received aid. 
Table F8: Access to aid and expectations, outcomes, and approval of government policies (balanced panel of full results)

\begin{tabular}{|c|c|c|c|c|c|c|c|c|c|}
\hline & \multicolumn{3}{|c|}{ All } & \multicolumn{3}{|c|}{ 0-4.5 FTE } & \multicolumn{3}{|c|}{$5+$ FTE } \\
\hline & April & July & Nov & April & July & Nov & April & July & Nov \\
\hline Expectation index & $\begin{array}{l}0.333^{* *} \\
(0.157)\end{array}$ & $\begin{array}{c}0.253^{* * * *} \\
(0.062)\end{array}$ & $\begin{array}{l}0.166^{* *} \\
(0.069)\end{array}$ & $\begin{array}{c}0.581^{* * * *} \\
(0.173)\end{array}$ & $\begin{array}{l}0.171^{*} \\
(0.090)\end{array}$ & $\begin{array}{c}0.086 \\
(0.104)\end{array}$ & $\begin{array}{c}0.185 \\
(0.249)\end{array}$ & $\begin{array}{c}0.357^{* * *} \\
(0.089)\end{array}$ & $\begin{array}{l}0.194^{* *} \\
(0.094)\end{array}$ \\
\hline Recover in two years & $\begin{array}{c}0.027 \\
(0.060)\end{array}$ & $\begin{array}{c}0.044 \\
(0.027)\end{array}$ & $\begin{array}{c}0.030 \\
(0.031)\end{array}$ & $\begin{array}{c}0.091 \\
(0.077)\end{array}$ & $\begin{array}{l}-0.002 \\
(0.040)\end{array}$ & $\begin{array}{c}0.027 \\
(0.047)\end{array}$ & $\begin{array}{l}-0.033 \\
(0.092)\end{array}$ & $\begin{array}{c}0.106^{* * * *} \\
(0.038)\end{array}$ & $\begin{array}{c}0.014 \\
(0.042)\end{array}$ \\
\hline Recover ever & $\begin{array}{l}0.035 \\
(0.028)\end{array}$ & $\begin{array}{c}0.018 \\
(0.012)\end{array}$ & $\begin{array}{l}0.035^{* *} \\
(0.016)\end{array}$ & $\begin{array}{c}0.060^{* * *} \\
(0.022)\end{array}$ & $\begin{array}{c}0.025 \\
(0.016)\end{array}$ & $\begin{array}{c}0.018 \\
(0.025)\end{array}$ & $\begin{array}{c}0.013 \\
(0.051)\end{array}$ & $\begin{array}{c}0.011 \\
(0.018)\end{array}$ & $\begin{array}{l}0.045^{* * *} \\
(0.021)\end{array}$ \\
\hline Expect future layoffs & $\begin{array}{c}-0.144^{*} \\
(0.077)\end{array}$ & $\begin{array}{c}-0.132^{* * *} \\
(0.039)\end{array}$ & $\begin{array}{l}-0.053 \\
(0.035)\end{array}$ & $\begin{array}{c}-0.229^{* *} \\
(0.112)\end{array}$ & $\begin{array}{c}-0.119^{* *} \\
(0.058)\end{array}$ & $\begin{array}{l}-0.050 \\
(0.052)\end{array}$ & $\begin{array}{l}-0.135 \\
(0.102)\end{array}$ & $\begin{array}{c}-0.151^{* * *} \\
(0.057)\end{array}$ & $\begin{array}{l}-0.065 \\
(0.049)\end{array}$ \\
\hline Prob of closure or bankruptcy & $\begin{array}{c}-0.090^{* *} \\
(0.037)\end{array}$ & $\begin{array}{c}-0.084^{* * *} \\
(0.017)\end{array}$ & $\begin{array}{c}0.013 \\
(0.047)\end{array}$ & $\begin{array}{c}-0.139^{* * *} \\
(0.045)\end{array}$ & $\begin{array}{c}-0.057^{* *} \\
(0.027)\end{array}$ & $\begin{array}{c}0.051 \\
(0.075)\end{array}$ & $\begin{array}{l}-0.068 \\
(0.057)\end{array}$ & $\begin{array}{c}-0.117^{* * *} \\
(0.023)\end{array}$ & $\begin{array}{l}-0.001 \\
(0.070)\end{array}$ \\
\hline Outcome index & $\begin{array}{c}0.184 \\
(0.132)\end{array}$ & $\begin{array}{c}0.288^{* * * *} \\
(0.057)\end{array}$ & $\begin{array}{l}0.173^{* *} \\
(0.073)\end{array}$ & $\begin{array}{c}0.155 \\
(0.184)\end{array}$ & $\begin{array}{l}0.138^{*} \\
(0.081)\end{array}$ & $\begin{array}{c}0.005 \\
(0.111)\end{array}$ & $\begin{array}{c}0.192 \\
(0.178)\end{array}$ & $\begin{array}{c}0.417^{* * *} \\
(0.078)\end{array}$ & $\begin{array}{l}0.223^{* *} \\
(0.097)\end{array}$ \\
\hline Perc. rev loss (Mar-Sep) & $\begin{array}{c}-6.599^{* *} \\
(3.357)\end{array}$ & $\begin{array}{c}-10.604^{* * *} \\
(2.344)\end{array}$ & $\begin{array}{l}-2.233 \\
(1.936)\end{array}$ & $\begin{array}{l}-5.232 \\
(4.704)\end{array}$ & $\begin{array}{l}-4.184 \\
(3.785)\end{array}$ & $\begin{array}{c}0.175 \\
(2.913)\end{array}$ & $\begin{array}{c}-8.445^{*} \\
(5.127)\end{array}$ & $\begin{array}{c}-15.128^{* * *} \\
(3.049)\end{array}$ & $\begin{array}{l}-2.053 \\
(2.733)\end{array}$ \\
\hline Past layoffs & $\begin{array}{l}-0.008 \\
(0.071)\end{array}$ & $\begin{array}{c}-0.081^{* * *} \\
(0.031)\end{array}$ & $\begin{array}{l}-0.028 \\
(0.034)\end{array}$ & $\begin{array}{l}-0.015 \\
(0.095)\end{array}$ & $\begin{array}{l}-0.061 \\
(0.042)\end{array}$ & $\begin{array}{c}0.031 \\
(0.051)\end{array}$ & $\begin{array}{c}0.022 \\
(0.092)\end{array}$ & $\begin{array}{c}-0.101^{* *} \\
(0.042)\end{array}$ & $\begin{array}{l}-0.021 \\
(0.043)\end{array}$ \\
\hline Permanently closed & $\begin{array}{c}0.000 \\
(0.000)\end{array}$ & $\begin{array}{c}-0.014^{* * *} \\
(0.005)\end{array}$ & $\begin{array}{c}-0.052^{* * *} \\
(0.015)\end{array}$ & $\begin{array}{c}0.000 \\
(0.000)\end{array}$ & $\begin{array}{c}-0.011^{* *} \\
(0.005)\end{array}$ & $\begin{array}{l}-0.018 \\
(0.025)\end{array}$ & $\begin{array}{c}0.000 \\
(0.000)\end{array}$ & $\begin{array}{c}-0.015^{*} \\
(0.009)\end{array}$ & $\begin{array}{c}-0.087^{* * *} \\
(0.022)\end{array}$ \\
\hline Approval index & $\begin{array}{c}0.612^{* * *} \\
(0.196)\end{array}$ & $\begin{array}{c}0.268^{* * *} \\
(0.065)\end{array}$ & $\begin{array}{c}0.441^{* * *} \\
(0.077)\end{array}$ & $\begin{array}{c}0.726^{* * * *} \\
(0.279)\end{array}$ & $\begin{array}{c}0.076 \\
(0.087)\end{array}$ & $\begin{array}{c}0.229^{* *} \\
(0.113)\end{array}$ & $\begin{array}{l}0.519^{*} \\
(0.272)\end{array}$ & $\begin{array}{c}0.407^{* * * *} \\
(0.096)\end{array}$ & $\begin{array}{c}0.558^{* * *} \\
(0.106)\end{array}$ \\
\hline Approve of SME policies & $\begin{array}{c}0.214^{* * *} \\
(0.074)\end{array}$ & $\begin{array}{c}0.222^{* * *} \\
(0.043)\end{array}$ & $\begin{array}{c}0.224^{* * *} \\
(0.037)\end{array}$ & $\begin{array}{l}0.244^{* *} \\
(0.103)\end{array}$ & $\begin{array}{c}0.095 \\
(0.063)\end{array}$ & $\begin{array}{c}0.144^{* * *} \\
(0.054)\end{array}$ & $\begin{array}{l}0.172^{*} \\
(0.099)\end{array}$ & $\begin{array}{c}0.303^{* * *} \\
(0.059)\end{array}$ & $\begin{array}{c}0.273^{* * *} \\
(0.051)\end{array}$ \\
\hline Approve of policies for workers & $\begin{array}{l}0.152^{* *} \\
(0.068)\end{array}$ & $\begin{array}{c}0.138^{* * *} \\
(0.043)\end{array}$ & $\begin{array}{c}0.164^{* * * *} \\
(0.038)\end{array}$ & $\begin{array}{c}0.141 \\
(0.096)\end{array}$ & $\begin{array}{l}0.026 \\
(0.061)\end{array}$ & $\begin{array}{c}0.087 \\
(0.055)\end{array}$ & $\begin{array}{l}0.169^{*} \\
(0.098)\end{array}$ & $\begin{array}{c}0.189^{* * * *} \\
(0.060)\end{array}$ & $\begin{array}{c}0.201^{* * * *} \\
(0.054)\end{array}$ \\
\hline Gov. reaction was appropriate & $\begin{array}{l}0.143^{* *} \\
(0.068) \\
\end{array}$ & $\begin{array}{c}0.045 \\
(0.042) \\
\end{array}$ & $\begin{array}{l}0.095^{* *} \\
(0.037) \\
\end{array}$ & $\begin{array}{l}0.214^{* *} \\
(0.094) \\
\end{array}$ & $\begin{array}{r}-0.011 \\
(0.060)\end{array}$ & $\begin{array}{c}0.021 \\
(0.052)\end{array}$ & $\begin{array}{c}0.041 \\
(0.099) \\
\end{array}$ & $\begin{array}{c}0.068 \\
(0.059) \\
\end{array}$ & $\begin{array}{c}0.141^{\text {**** }} \\
(0.052)\end{array}$ \\
\hline Number of respondents & 939 & 1,987 & 1,470 & 553 & 1,188 & 869 & 386 & 796 & 601 \\
\hline
\end{tabular}




\section{G Appendix: Applications to specific programs}

This section provides details on applications to specific programs. Of the 2,452 respondents of the July follow-up survey, 646 (26 percent) filled out information about applications and outcomes of specific programs. ${ }^{30}$ The vast majority (93 percent) of firms that responded to this section of the survey are formal. Overall, 74 percent of firms who report applying or signing up for a relief program do so only for one. About 18 percent applied to two programs. It is rare $(<8$ percent) that firms apply to three or more programs. Table G2 shows the programs the received the most applications by country. Table G1 breaks down the number of applications by formality status.

There are 150 firms with information about the time to hear back about the programs to which they applied. Figure G1 shows the average time to hear back from programs, conditional on applying. If a respondent applied to more than one program, their wait time was averaged. On average, firms with more than five employees experienced longer wait times. This difference was largely driven by applications to loan programs.

Table G1: Number of applications by formality status

\begin{tabular}{lcccc}
\hline N of programs & Formal & Informal & Formality missing & Total \\
\hline $\mathbf{1}$ & 358 & 79 & 42 & 479 \\
$\mathbf{2}$ & 97 & 7 & 9 & 113 \\
$\mathbf{3}$ & 31 & 1 & 2 & 34 \\
$\mathbf{4}$ & 13 & 1 & 0 & 14 \\
$\mathbf{5}$ & 2 & 1 & 0 & 3 \\
$\mathbf{6}$ & 2 & 0 & 0 & 2 \\
$\mathbf{7}$ & 0 & 0 & 0 & 0 \\
$\mathbf{8}$ & 0 & 0 & 1 & 1 \\
\hline Total & $\mathbf{5 0 3}$ & $\mathbf{8 9}$ & $\mathbf{5 4}$ & $\mathbf{6 4 6}$ \\
\hline
\end{tabular}

Note: Table shows number of applications by formality status, where formality status is determined by making social security contributions.

\footnotetext{
${ }^{30}$ Respondents were shown this part of the survey if they reported submitting an application or trying to submit one.
} 
Figure G1: Number of days to hear back by firm size
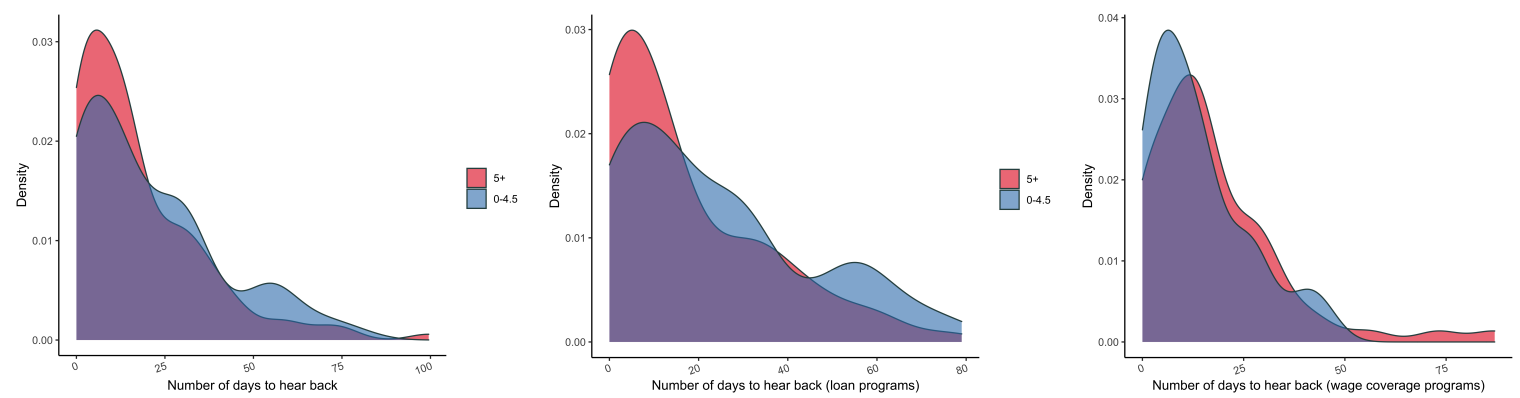

Note: The left plot shows number of days to hear back by firm size. The center and right plots break out trends by program type.

Table G2: Programs that received the most applications by country

\begin{tabular}{llc}
\hline Country & Program & $\mathbf{N}$ \\
\hline Argentina & Programa de Asistencia de Emergencia al Trabajo y la Producción & 16 \\
\hline Bolivia & Programa Especial de Apoyo a la Micro, Pequeña y Mediana Empresa & 10 \\
\hline Brazil & Programa Emergencial de Acesso a Crédito & 77 \\
& BNDES Credito Pequenas Empresa & 62 \\
& Programa Emergencial de Manutencao do Emprego e da Renda & 33 \\
\hline Chile & Ampliación FOGAPE & 167 \\
& Suspensión del contrato de trabajo por acto de autoridad & 59 \\
\hline Colombia & Pacto de suspensión del contrato de trabajo & 53 \\
\hline Dominican Republic & Subsidio del gobierno para pagar nominas & 109 \\
\hline Mexico & Créditos solidarios a palabra & 21 \\
\hline Peru & Reactiva Perú & 107 \\
\hline
\end{tabular}

Note: Table shows the programs the received the most applications in each country. For additional details on these programs, see Tables A2 and A3. 


\section{H Appendix: Testimonials}

\section{How has COVID-19 affected your business?}

"On one hand, our sales were affected because people are more reluctant to spend and, on the other hand, because it's impossible to make shipments due to the mandatory quarantine." (Argentina, April 10, 2020)

"We are a small business supplying goods for the hotel and restaurant industry in Chile. Due to COVID-19 ALL of my clients have closed their doors until July 1, at least. My suppliers in China have increased their prices exorbitantly and there is no transportation to ship the merchandise. Also, the United States is confiscating essential merchandise (masks, etc.) that pass through its ports, which makes it impossible to import them and adapt to what that the market is buying." (Chile, April 11, 2020)

What could the government do to help businesses like yours?

"I think an ideal initiative would be to give out credit to SMEs with 0 percent interest to incentivize production. Or make competitive funds available." (Bolivia, April 3, 2020)

"In my case, I can access loans to obtain more capital; however, there are many prerequisites, the time until disbursement is too long, and the interest is too high." (Bolivia, April 5, 2020)

Please explain in your own words how your was experience looking for or applying for assistance programs.

"There are programs sponsored by SERCOTEC, CORFO, SENCE. I applied to the one by SERCOTEC, along with other 60,000 other firms. I was rejected and the justification was a lie (that I did not enter my tax information). In practice, they gave out less than 3,000 credits and the other 57,000 firms were turned down. It's funny that they do so much advertising encouraging us to participate." (Chile, July 7, 2020)

"A total frustration. We are a small firm, banks give Reactiva Peru loans to medium and large firms, because our annual output seems too low to them. Also, other banks required us to have outstanding debt with them or an active account with them. Unfortunately, there is no one we can go to complain or appeal." (Peru, July 1, 2020) 